\title{
MINERALOGY, GEOCHEMISTRY AND GENESIS OF MOLLAAHMAD PASS BENTONITE DEPOSIT, NAEIN, ISFAHAN PROVINCE, IRAN
}

\author{
Shirin FATAHI ${ }^{1)}$, Mohamadali MACKIZADEH ${ }^{2)}$ *, Nader KHANI ${ }^{2)}$ and Sima BAYAT ${ }^{1)}$ \\ 1) Department of Earth Sciences, Faculty of Natural Sciences, University of Tabriz, 51666, Tabriz, Iran \\ ${ }^{2)}$ Department of Geology, University of Isfahan, 8174673441, Isfahan, Iran
}

*Corresponding author 's e-mail: Ma.makizadeh@sci.ui.ac.ir

\section{ARTICLE INFO}

\section{Article history:}

Received 8 August 2019

Accepted 16 January 2020

Available online 21 February 2020

\section{Keywords:}

Bentonite

Geochemistry

Rare earth elements

Lacustrine

Mollaahmad Pass

Iran

\begin{abstract}
The Mollaahmad pass bentonite deposit occurs within an area of about $10 \mathrm{~km}^{2}$ with Oligo-Miocene age (Isfahan- Iran). This bentonite deposit with two general lenticular and layered forms has extended in the tuff, conglomerates and sandstones (including volcanic fragments). XRD studies are demonstrating that montmorillonite, montmorillonite-illite, nontronite, albite, anorthite and quartz are major and clinoptilolite, heulandite, sanidine, orthoclase, calcite, microcline and actinolite are minor constituent minerals in studied bentonite deposit. Moreover, mineral chemistry indicates that Mollaahmad pass bentonite deposit has intermediate to di-octahedral smectites, so it can be classified as Wyoming bentonite type. Based on geochemical studies, transform process of parent rocks into bentonite was accompanied by enrichment of $\mathrm{Cr}, \mathrm{Sb}, \mathrm{Se}$ and REEs, and also enrichment or depletion of other major and trace elements. More geochemical studies have shown positive to negative $\mathrm{Eu}$ and $\mathrm{Ce}$ anomalies. This can be related to change in rate of oxidation and alteration intensity in altered system. In addition, study of rare earth elements indicates high differentiation of LREEs from HREEs that related to egress of HREEs from environment in form of carbonate complexes. It seems that six factors including discrepancy in rate of alteration intensity of the source materials, incorporation in crystal lattice, complex-forming ligands, surface adsorption and difference in stability of primary minerals are able to control mobilization, differentiation and distribution of elements in studied bentonites. This bentonite deposits has formed in margin of lacustrine environment.
\end{abstract}

\section{INTRODUCTION}

According to Parker (1988), bentonite is a rock composed of plastic clays with high colloids that result from montmorillonite and smectite during chemical alteration of volcanic ash. Bentonite deposits may be formed by any of the following three mechanisms: 1) diagenetic alteration of volcanic glass in an aqueous environment, 2) hydrothermal alteration of volcanic glass, and 3) formation of smectite-rich sediments in salt lakes and sabkha environments (Christidis and Huff, 2009; Guven, 1988).

The concentration of alkaline elements and $\mathrm{pH}$ in solutions are responsible from alteration, different products that can be formed such as zeolites, types of silicate polymorphs, feldspars, hydroxides, calcium or aluminum hydrated silicates and carbonates (Savage et al., 2007; Knetchel and Patterson, 1962; Elzea and Murray, 1990). Based on chemical composition, bentonites are classified as intermediate $\mathrm{Na}-\mathrm{Ca}$ with high to moderate swelling ability, $\mathrm{Ca}$ - bentonite type with low swelling ability, bentonites with low to moderate swelling ability and K-bentonites (Grim and Kulbicki, 1961). The swelling properties were affected by mineralogy expressed by the CEC presence of smectite. The presence of some mineral phases (silica compounds) decreases swelling and gelling (Karakaya et al., 2011a).

If bentonite formed in a closed system, after initial dehydration and cation exchange between flux phase and volcanic glass, alkaline and earth alkaline elements would release and cause increasing of $\mathrm{pH}$ and salinity in flux phase.

Smectites usually are formed in primary stage of alteration when $\mathrm{Na}^{+}+\mathrm{K}^{+} / \mathrm{H}^{+}$activity ratio in flux phase is low (Sheppard and Gude, 1973; Hay, 1987; Christidis, 2001). In fact, removal of alkalis and high activity of $\mathrm{Mg}$ improve formation of smectite (Hay, 1977; Senkayi et al., 1984). When $\mathrm{Na}^{+}+\mathrm{K}^{+} / \mathrm{H}^{+}$ratio activity is high, zeolite will be formed instead of smectite.

There are various bentonite deposits in Mollaahmad Pass, and their unique sequence have been observed in the Mehrabad, Chahbashe and Bash areas. During past decades, bentonite deposits in different parts of the world have been studied in detail for their origin, genesis, and behavior of major, trace, and 


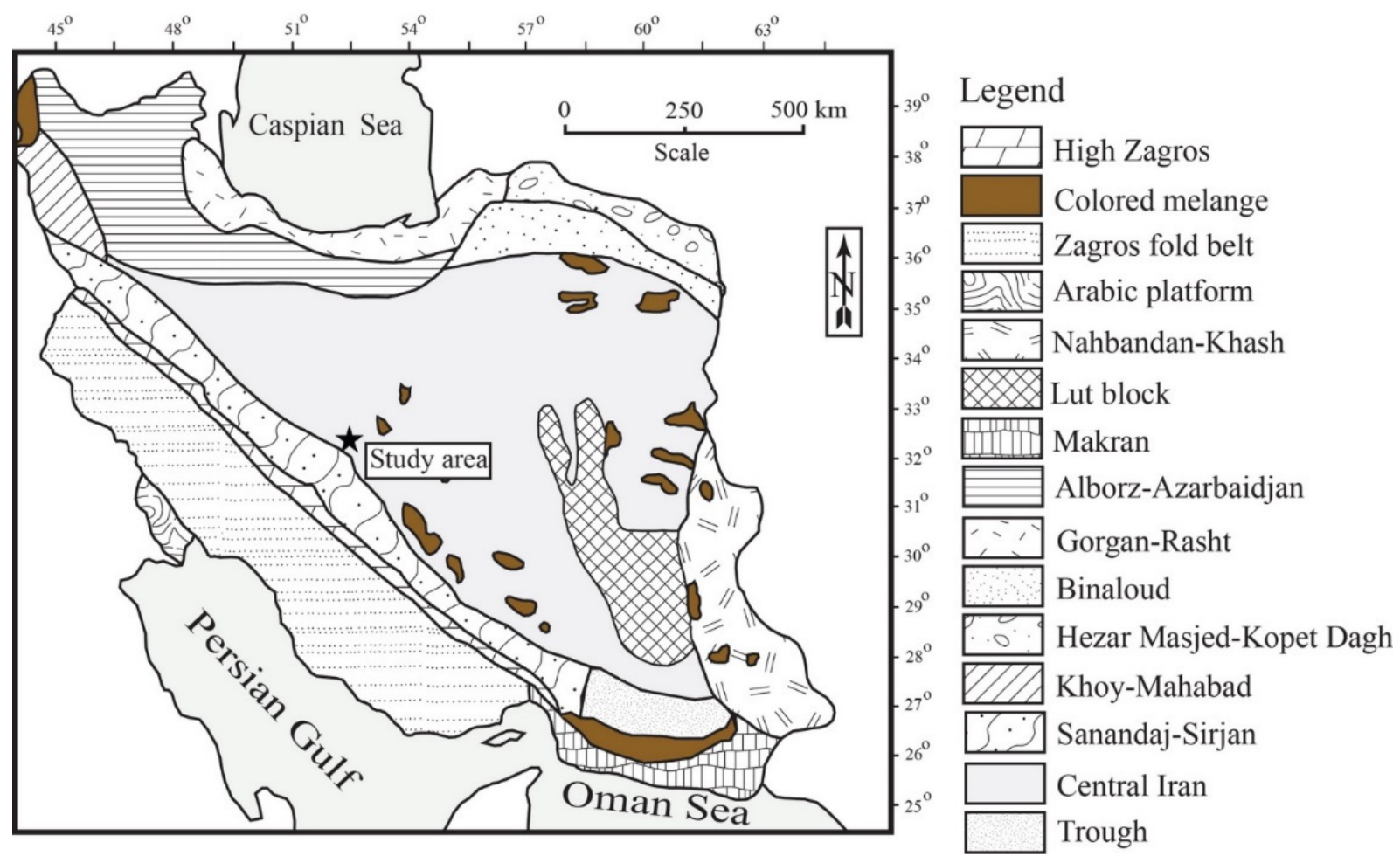

Fig. 1 Classification of tectonic units of Iran (Nabavi, 1976) with some modification and the location of the study area.

especially rare earth elements by many researchers (Hong et al., 2019; Ge et al., 2019; Köster et al., 2019; Pointon et al., 2018; Kadir et al., 2017; Kadir et al., 2019; Arslan et al., 2010; Abdioglu and Arslan, 2005; Ozdamar et al., 2014; Jiang et al., 2003; Karakaya et al., 2011a; Karakaya et al., 2011b; Modabberi et al., 2019; Calagari et al., 2015; Fatahi et al., 2015; Abedini et al., 2011). However, no comprehensive investigations on the Mollaahmad Pass bentonite deposit, especially in Bash and Chahbashe areas, have been carried out previously, particularly their mineralogy, geochemistry and origin of the occurrence. In this contribution, we suggest relatively comprehensive data on mineralogical characteristics, factors controlling the mobility, distribution, enrichment and depletion of major, trace, and rare earth elements during evolution of this deposit.

\section{SAMPLING AND EXPERIMENTAL METHODS}

Considering the lithological variations in study area, about 70 samples from bentonites and accompanying rocks were collected. The laboratory investigations started with preparation of thinpolished sections in Kimia Pajooh Alborz Company, Isfahan-Iran. Forty thin-polished samples were prepared for petrographic examinations (study of thinpolished samples carried out by transmission polarizing Olympus microscope, $\mathrm{BH}-2$ model and reflectance polarizing BX-60 model in Isfahan University). Then, two samples analyzed by XRD method for determination of minerals in bentonite (Faculty of Mining Engineering, Tehran University). Analytical properties were: D8- Advanced model,
Manufactured by Bruker axes, $\theta$ - $\theta$ type of device with $\mathrm{CuK} \alpha=1.5418 \mathrm{~A}^{\circ} \mathrm{X}$-ray, $2-702^{\circ} \theta$ scanning range and using $40 \mathrm{kV}$ and $30 \mathrm{~mA}$.

After separation of clay particles (with size less than $2 \mu \mathrm{m}$ ), their composition with one sample of bitumen determined in 5 and 7 points by electron microscope SEM-EDS (scanning electron microscope - energy dispersive spectroscopy) in Razi Metallurgical Institute, Tehran. In order to determine chemical composition in bentonites and their enclosing rocks, 16 samples were selected and analyzed using XRF (for major and minor oxides) and ICP-MS (for trace and rare earth elements) in Zarazma Laboratory, Tehran. For the purpose of chemical analysis, all samples were dried at a temperature less than $60{ }^{\circ} \mathrm{C}$ then dried samples were crushed to - 80 mesh and 25 gr was ground $(<150$ mesh) by steel ring and puck mill. A total of $0.2 \mathrm{~g}$ of these samples was carefully weighted and 1.5 gr Li-borate/ $\mathrm{Li}_{2} \mathrm{~B}_{4} \mathrm{O}_{7}$ fluxing graphite crucible was added to each sample. These samples were heated at $980{ }^{\circ} \mathrm{C}$ for about 30 minutes. Each sample was dissolved in $100 \mathrm{ml}$ $\mathrm{HNO}_{3}(5 \%)$ and poured into a polypropylene test tube for the measuring process. Chemical analyses were controlled by analyzing the calibration and verification standard. In order to determine the major and minor of samples, X-ray fluorescence (XRF) and a specific ion electrode (SIE) were used, respectively. The detection limit for major and minor oxides was $0.05 \mathrm{wt} \%$. Trace and rare earth elements identified by ICP-MS method with analytical code (MMS-01HF/Multi acid digestive) and (MMS-02-digestion using HF). For determining of trace elements, four 


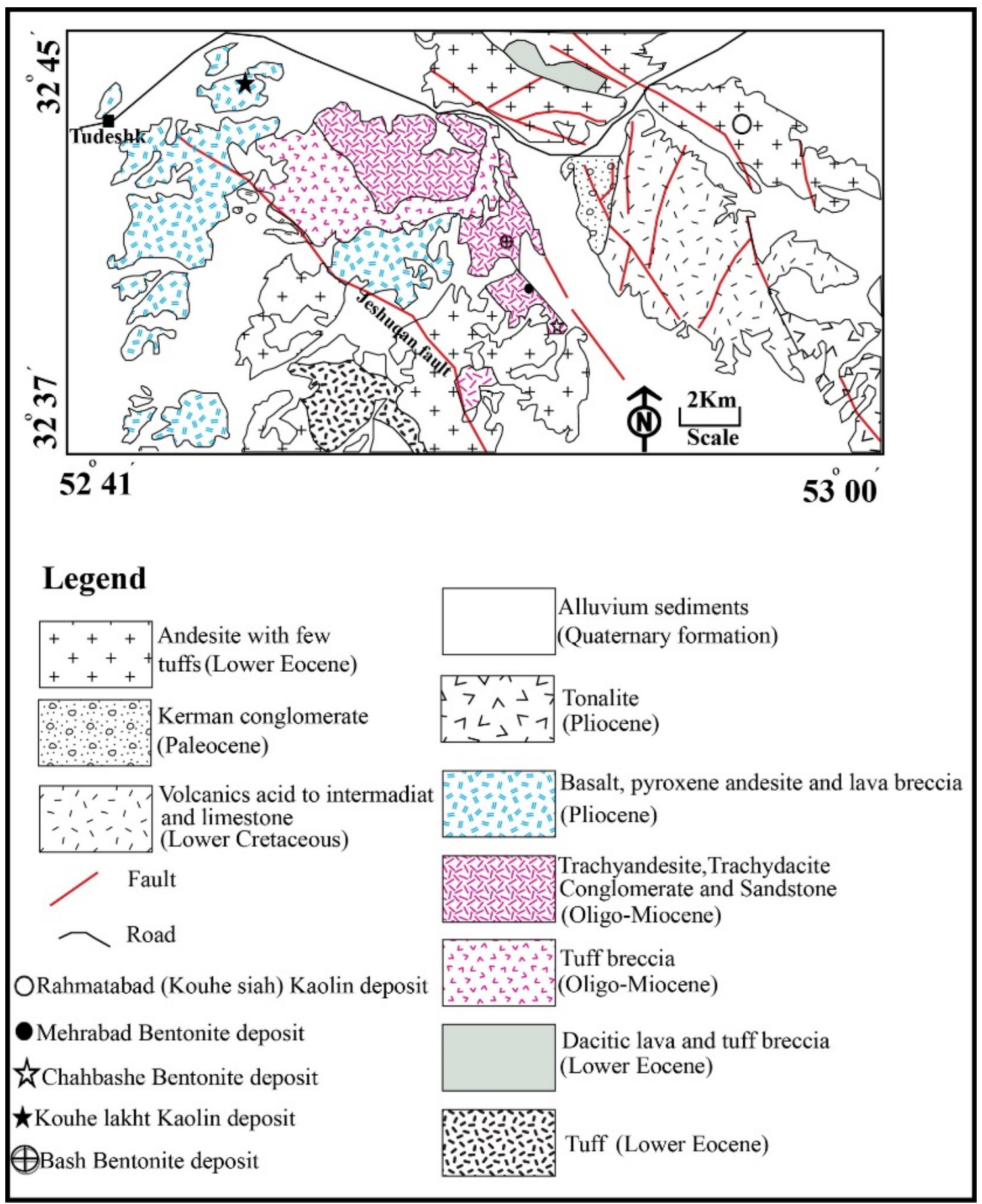

Fig. 2 Geologic map of the study area illustrating the position of different types of industrial soils in Mollaahmad Pass.

acids including $\mathrm{HNO}_{3}, \mathrm{HClO}_{4}, \mathrm{HCl}$ and $\mathrm{HF}$ used. The rare earth elements are type of refractory elements, so they need to stronger extraction analysis with use of multi-acids and microwave digestion. Then, the final solution was analyzed by ICP-MS.

\section{RESULTS AND DISCUSSION}

\subsection{GEOLOGY}

Mollaahmad area with geography coordinates $52^{\circ}, 47^{\prime}, 54^{\prime \prime}$ to $52^{\circ}, 50^{\prime}, 07^{\prime \prime}$ longitude and $32^{\circ}, 37^{\prime}, 24^{\prime \prime}$ to $32^{\circ}, 39^{\prime}, 08^{\prime \prime}$ latitude is located $\sim 25 \mathrm{~km}$ Southwest of Naein (Isfahan Province, Iran). According to
Nabavi (1976), this area is a part of Central Iran structural zone and near to the Urumieh-Dokhtar magmatic belt (Fig. 1).

The major lithologic units in Mollaahmad pass ranges from the oldest to the youngest include: volcanic rocks and limestone (Lower Cretaceous), Kerman conglomerate (Pliocene), andesite with few tuffs (Lower Eocene), tuffite units (Lower Eocene), dacitic lava and tuff breccia (Lower Eocene), trachyandesite, tuff, conglomerate, and sandstone with volcanic fragments, host of bentonite (Oligomiocene), basalt and pyroxene andesite and lava breccia 


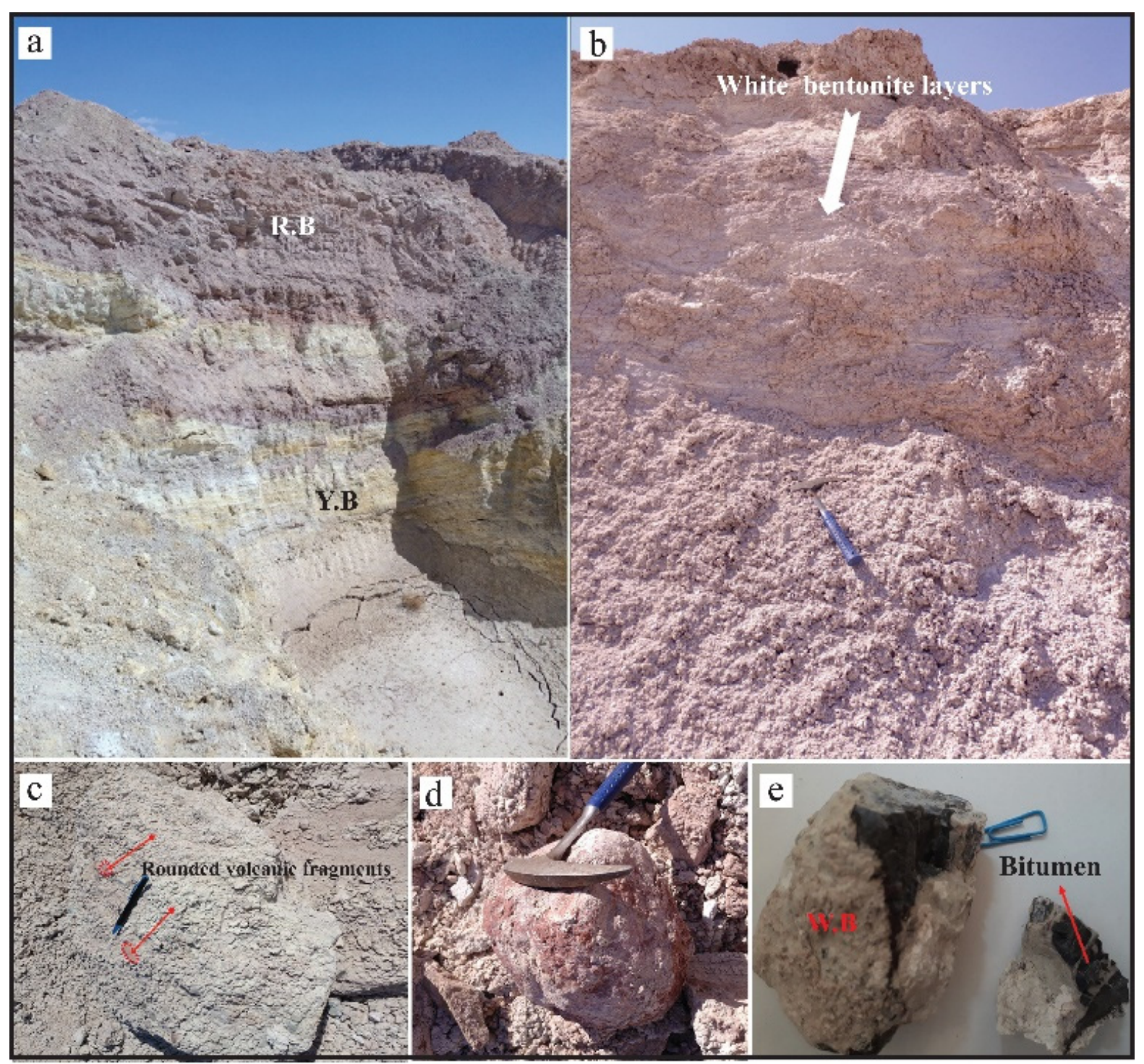

Fig. 3 The view of a) alternation of red and yellow bentonites along V1 profile, b) white bentonite along V2 profile. As seen, despite bentonitization, the primary bedding of parent rock is remained, c) polymictic conglomerates with rounded semi- altered volcanic fragments, d) rounded volcanic boulder that transported by river into Oligo-Miocene sedimentary basin. Volcanic glass extensively replaced by Fe/oxides and the silica percolated to their cavities during bentonitization process.

(Pliocene), tonalite (Pliocene) and Quaternary alluvial sediments (Amini and Amini Chehraq, 2003) (Fig. 2).

In Mollaahmad Pass, during alteration and weathering of volcanic, volcano-sedimentary and sedimentary rocks, the multiple bentonite deposits (such as Mehrabad, Chahbashe, Bash) and kaolin deposits (such as Rahmatabad and Kohelakht) with Eocene-Oligocene and Pliocene age have formed. Generally, the Mollaahmad Pass bentonite deposits with area about $10 \mathrm{~km}^{2}$, has Oligo-Miocene age with two general lenticular and layered forms that extended in tuff, conglomerate and sandstone including volcanic fragments and few rounded basaltic, andesitic, dacitic rubbles. Sampling from these alteration products has been done along two sections with approximately 40 meters in thickness for each one (V1 and V2 profiles).
Despite occurrence of alteration, the primary bedding of parent rocks in bentonite units has remained (Figs. 3a and b). Fresh conglomerate and sandstone containing volcanic fragments with clear bedding and interlayering of clays and silts can be seen among bentonites (Fig. 3c). Volcanic boulders are observed in bentonite layers that transported to sedimentary basin by rivers (Fig. 3d). Moreover, presence of organic matter -rich layers in white bentonite, is considered as unique features of these ores (Fig. 3e). The stratigraphy column of study units is illustrated in Figure 4 . The best recognizable lithological sequence along the V1 profile from surface to depth include: Quaternary alluvium (cap rock), alternation of red and yellow bentonites (OligoMiocene) and tuff breccia with Oligo-Miocene age (bed rock). Meanwhile, along V2 profile and perpendicular to bentonite layers from up to down, 

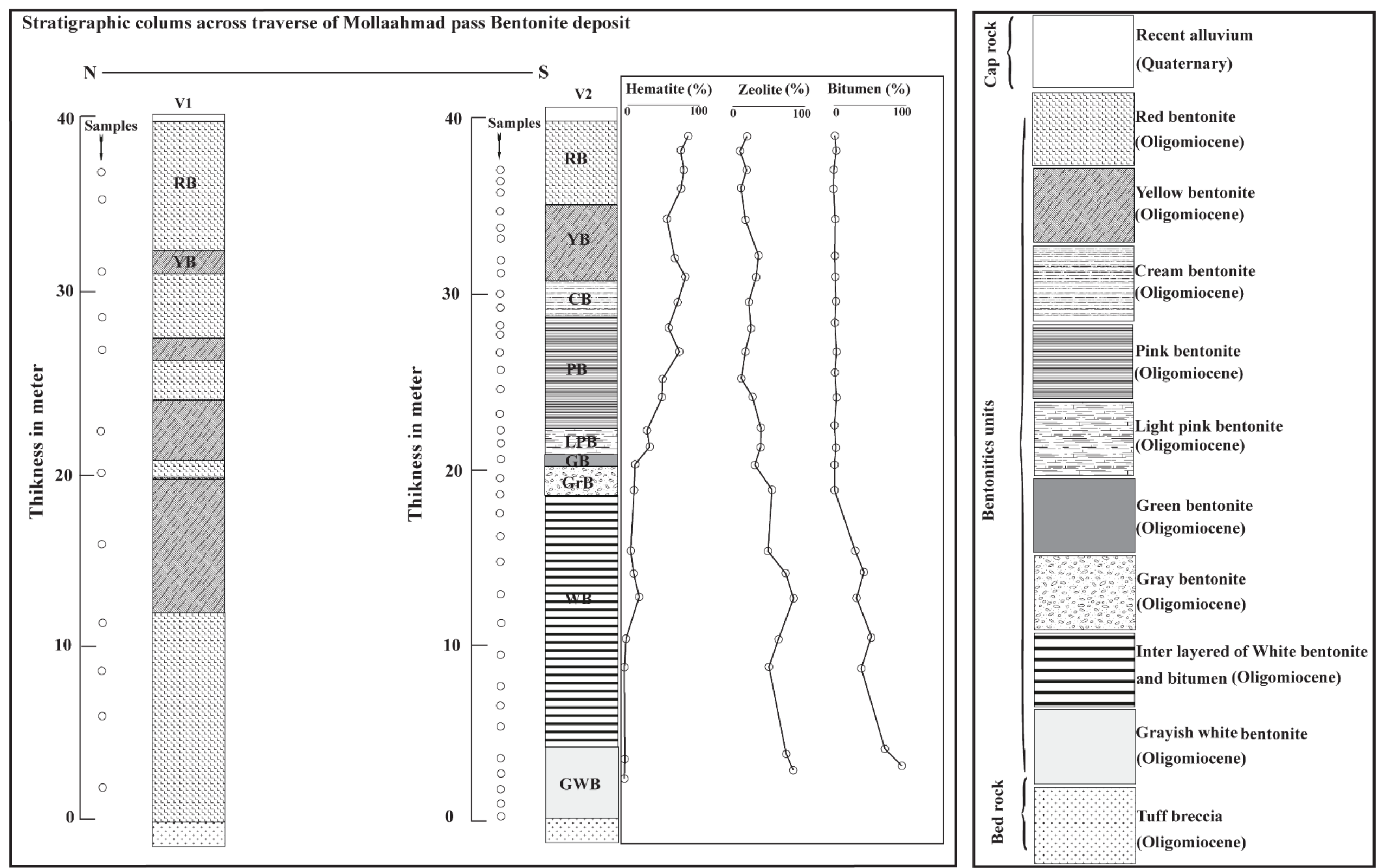

Fig. 4 Stratigraphic column of study bentonite in 2 profile (V1 and V2), across bentonite layers. 


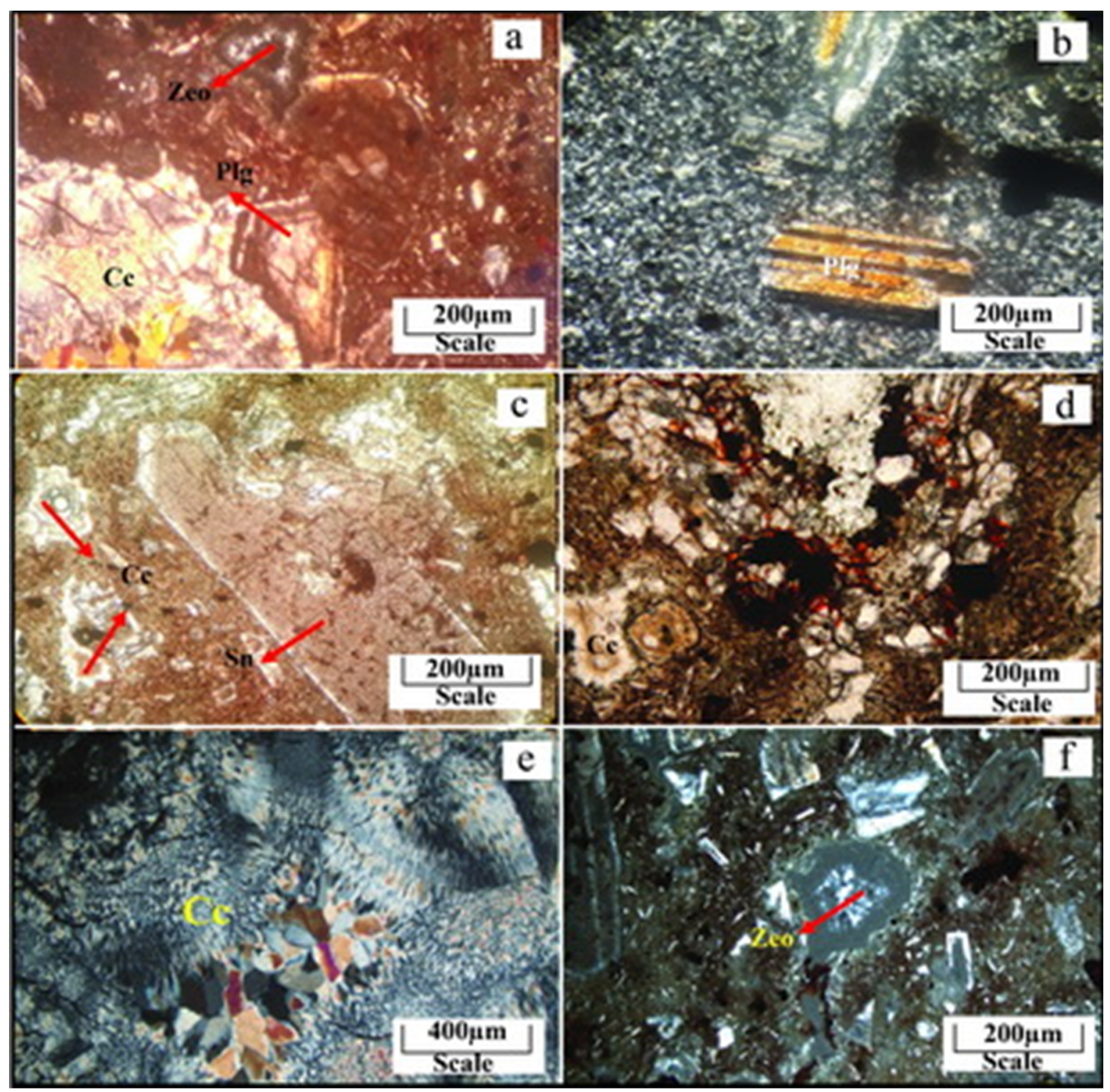

Fig. 5 Photomicrographs of andesite; a) plagioclase crystals with dusty margin accompanied by zeolite and chalcedony(cross polarized light, XPL), b) Phenocrysts of plagioclase with polysynthetic twinning (XPL), c) Sanidine crystals decomposed to clay minerals, also chalcedony as filling volcanic cavities (PPL), d) Opaque minerals that converted to Fe oxides/hydroxides (XPL), e) Chalcedony that filling the open space of cavities (XPL), f) growth of Zeolite crystals in open space of cavities (XPL), Sn=Sanidine, $\mathrm{Plg}=$ Plagioclase, $\mathrm{Cc}=$ Chalcedony, Zeo=Zeolite (abbreviation of minerals from Kretz, 1983 and Whitney and Evans, 2010).

lithologies such as tuff breccia with Oligo-Miocene age (bedrock), grayish- white bentonite, white bentonite with interlayers of bitumen, gray, green, low pink, pink, creamy, yellow and red bentonites with Oligo-Miocene age and Quaternary alluvium (cap rock) are visible. According to field observations, yellow, creamy, low pink, pink and red clays (that contain hematite and goethite minerals) are located in the top layers (towards the increase in oxidation conditions). However, interlayers of bitumen and sporadic pyrite with zeolite, mostly located in deep section of sedimentary basin. Other important properties of studied bentonites can be pointed out to folding, popcorn texture in white bentonite, soapy feel, conchoidal fracture surface, low hardness/ density and coexistence of interlayers of gypsum in all types of bentonite units. In addition, coarse-grained calcite, chalcedony and zeolites examined as filling cavities in volcanic boulders and sometimes as veinlets within bentonites.

According to field observations, the silica can be seen in 3 forms: 1- black chert: the quartz mineral in volcanic fragments have not suitable composition for reaction by fluids responsible alteration in system and then they remain in the form of sporadic black chert in bentonite body. These quartzes have euhedral form. 2Chalcedony: during alteration of suitable and reactive phase such as plagioclase, pumice debris and shard glass by fluids, a silicate gel can be produced that transported to cavities and other open space filling 


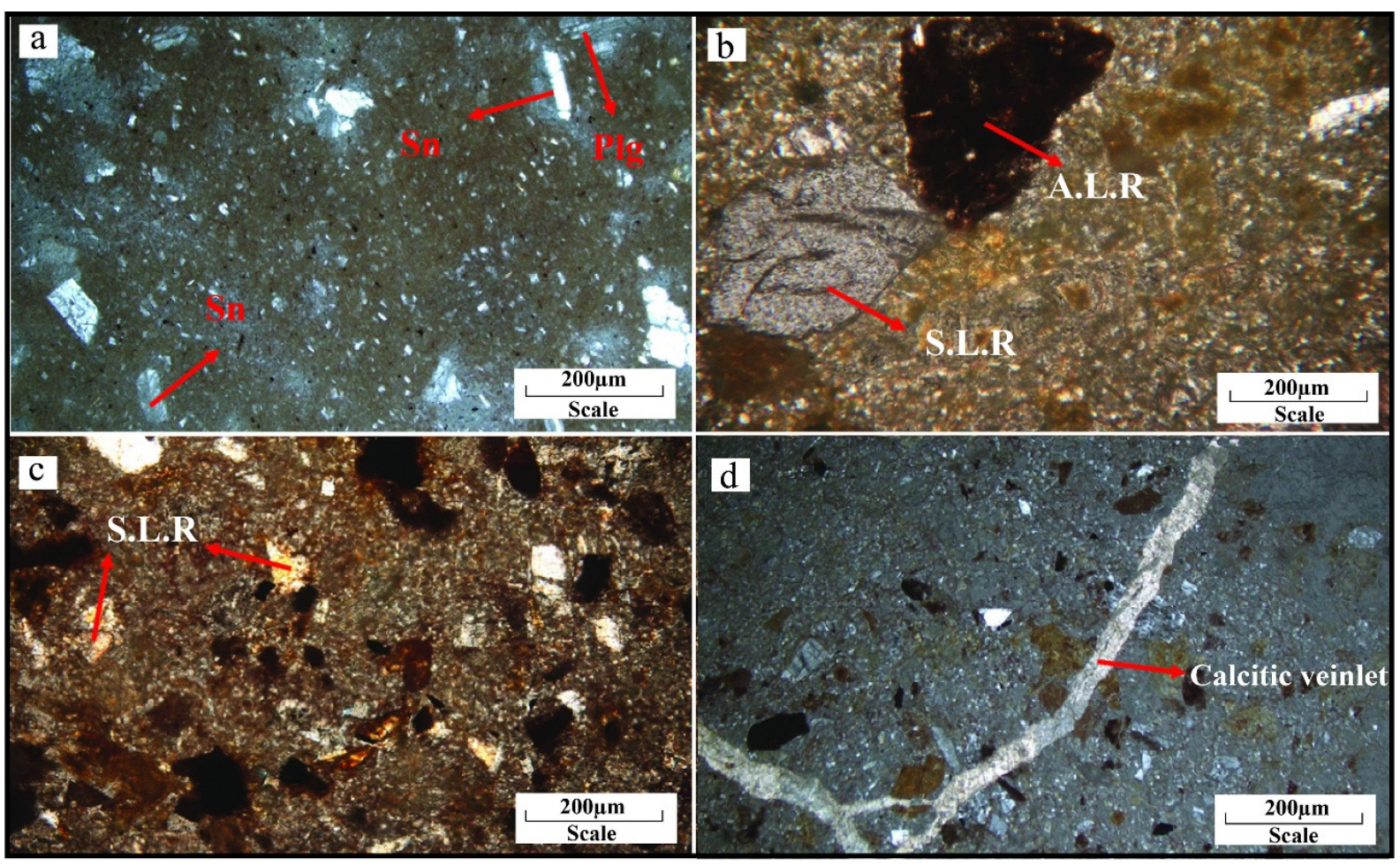

Fig. 6 Photomicrographs of tuff a) sanidine crystals with Carlsbad twining and plagioclase with polysynthetic twinning, b) andesitic and carbonate coarse fragments, c) carbonate rock fragments, d) carbonate veinlets that across the rock sample, all pictures prepared in XPL, A.L.R=Andesitic lithic rock, S.L.R=Sedimentary lithic rock, $\mathrm{Sn}=$ Sanidine, $\mathrm{Plg}=$ Plagioclase.

texture such as fractures then precipitate as the sporadic chalcedony veinlets within the bentonites. 3- Agate: this type of quartz transported by river into sedimentary basin and have rounded to semi-rounded forms.

\subsection{PETROGRAPHY}

\subsubsection{PETROGRAPHY OF ANDESITES}

Microscopic examinations show that the andesite at Mollaahmad Pass contain, plagioclase (about $60 \%$ ), sanidine (about $8 \%$ ), opaque minerals (about $5 \%$ ), chalcedony (about $5 \%$ ) and zeolite crystals (about $2 \%$ ) that surrounded in microlithic matrix (about $20 \%$ ) (Figs. 5a to f). Plagioclase occurs as dusty and resorbed margins (Fig. 5a) with polysynthetic twinning and sieve texture (Fig. 5b). Sanidine crystals occur as bayonet form, which decomposed into clay minerals (Fig. 5c). Opaque minerals converted to Fe- oxides and hydroxides (Fig. 5d). Chalcedony (Fig. 5e) and zeolites (Fig. 5f) make open space fillings as well as amygdaloidal shapes in cavities.

\subsubsection{PETROGRAPHY OF TUFF}

Microscopic study demonstrated, trachytic tuffs include sanidine and plagioclase crystals (about $55 \%$ and $15 \%$, respectively), volcanic glass (about $20 \%$ ), sedimentary (specially carbonates, about $4 \%$ ) and volcanic rock fragments (about $3 \%$ ) with opaque minerals (about $3 \%$ ) (Figs. 6 a to d). The sanidine and plagioclase crystals have Carlsbad and polysynthetic twining, respectively (Fig. 6a). The andesitic rock fragments have porphyry texture and include dispersed phenocrysts of plagioclase in fine-grained matrix of microlite and glass. This matrix replaced by clay minerals and Fe-oxides/hydroxides, so converted to brown and red color. Accompanied minerals are biotite and amphibole that remained intact from alteration process.

\subsubsection{PETROGRAPHY OF BENTONITIC SANDSTONE}

According to mineralogical investigations, sandstones include: volcanic (about $50 \%$ ), volcanosedimentary (about $35 \%$ ) and sedimentary rock fragments specially carbonates (about $5 \%$ ), quartz (about $7 \%$ ), biotite (about $1 \%$ ) and plagioclase (about $2 \%$ ) (Figs. 7a to i).

The volcanic rock fragments are andesitic (about $75 \%$ ), basaltic (about $20 \%$ ) and rhyolithic (about $5 \%$ ) types. The volcano-sedimentary rock fragments associated with shard glass (about $70 \%$ ), pumice debris (about $25 \%$ ) and fine-broken fragments of ignimbrites (about $5 \%$ ). The rhyolitic rock fragments indicate high quartz and sanidine crystals in glass matrix (Fig. 7a). Andesitic rock fragments recognized by phenocrysts of plagioclase within microlithic matrix (Fig. 7b). However, basaltic rock fragments contain plagioclase and olivine (Fig. 7c). As mentioned above, sedimentary rock fragments are especially carbonates that diagnosed with iridescent color (Fig. 7b). Rounded quartz (Fig. 7d) and biotite 


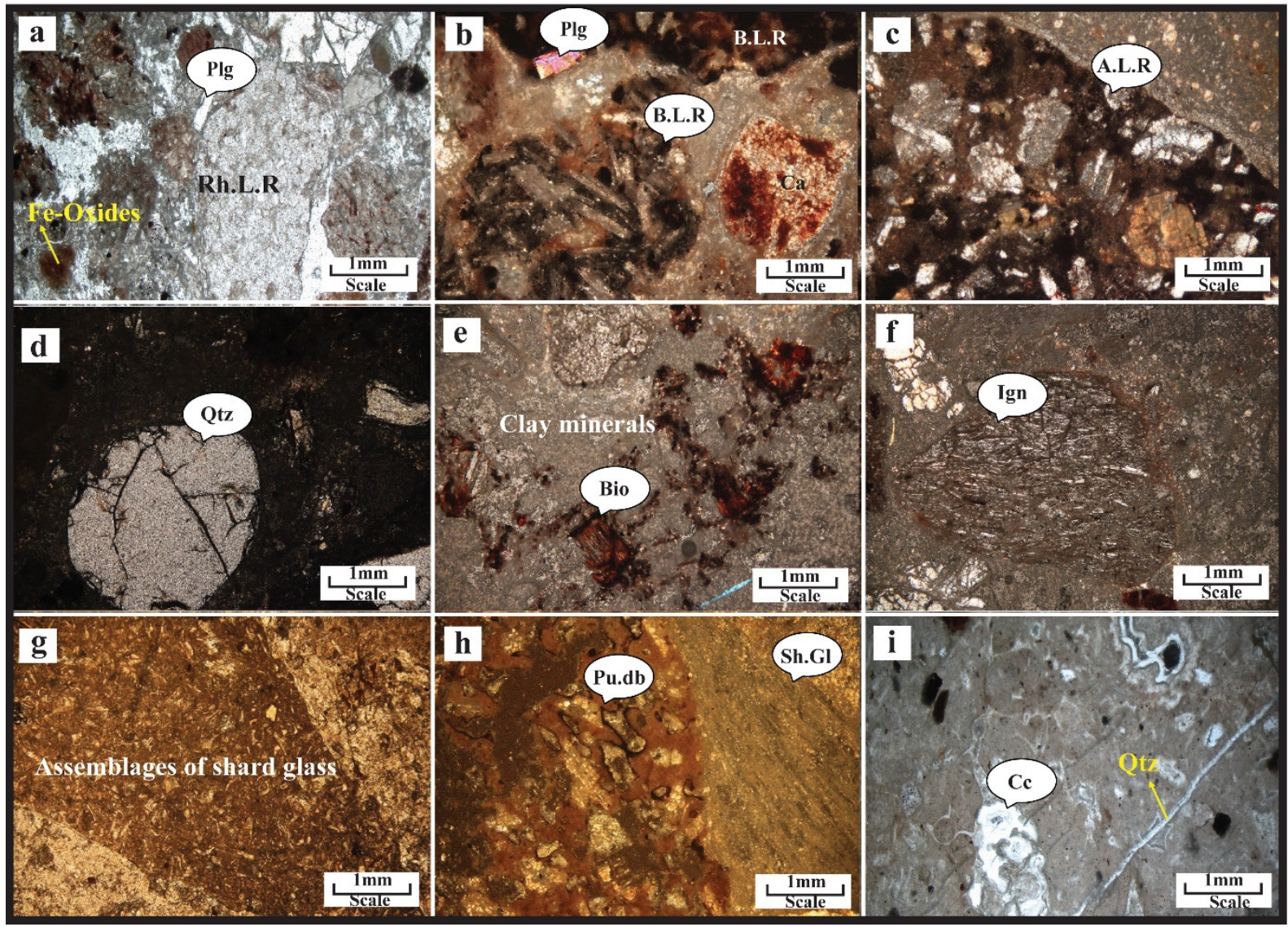

Fig. 7 Photomicrographs of sandstone and conglomerates. a) The semi-rounded rhyolithic rock fragments , b) the semi-rounded basaltic rock fragments, c) the andesitic rock fragments in conglomerate, d) sporadic biotite in bentonite that immune from alteration process, e) biotite without alteration in clay minerals, $\mathrm{f}$ ) ignimbrite broken fragments, g) assemblages of shard glass with fantasia form that cemented by Fe-oxides/hydroxides, h) the vacuolar pumice debris that primary circular cavities changing to oval form due to tectonic stress with shard glass that replaced by zeolite, i) chalcedony filling the open space, all pictures prepared in XPL. A.L.R=Andesitic lithic rock, Rh.L.R=Rhyolithic lithic rock, Qtz=Quartz, $\mathrm{Plg}=$ Plagioclase, $\mathrm{Bio}=$ Biotite, $\mathrm{Ign}=$ Ignimbrite, $\mathrm{Pu}=$ Pumice debris, $\mathrm{SH}=$ Shard glass, $\mathrm{Cc}=\mathrm{Chalcedony}$. (Abbreviation of minerals from Kretz, 1983 and Whitney and Evans, 2010).

(Fig. 7e) observed in samples that appear immune from alteration process.

In fine-broken fragments of ignimbrites, directed volcanic glass are visible that exposed to alteration (Fig. 7f). The assemblages of shard glass have fantasia forms (such as dagger, crescent and blade like) (Fig. 7g). The pumice debris are discerned by vascular form. These vascular forms have initially been circular form, but after exerting tectonic stress deformed to oval form (Fig. 7h).

Sometimes, zeolite and chalcedony (due to release of silicate gel during alteration of plagioclase and shard glass) fill cavities in bentonitic sandstones (Fig. 7i).

\subsubsection{CLASSIFICATION OF MOLLAAHMAD PASS SANDSTONES}

According to mineralogical investigations, the Mollaahmad Pass sandstones have $70 \%$ rock fragments $(60 \%$ volcanic and $10 \%$ sedimentary fragments), $8 \%$ quartz and $20 \%$ feldspars that surrounded by clay mineral matrix (about $10 \%$ ). According to the Folk (1974) classification, they are volcanic arenite (Fig. 8). In point of mineralogical view, this type of sandstones due to presence of unstable minerals such as biotite, volcanic glass and pumice debris are immature, and because of the moderate sorting and rounding have sub-mature texture.

\subsubsection{PETROLOGY OF ORGANIC MATERIAL}

According to field considerations, interlayers of organic material and white bentonite are visible in depth of sedimentary basin. In addition, the primary wood texture remained in some parts. Silica from bentonitization process (due to destruction of plagioclase and shard glass) permeate to open space of wood texture by fluids and begin to precipitate (Figs. 9a and b). Due to effect of tectonic pressure or diagenesis process, the initial wood texture has folded in some parts (Fig. 9a). Signature of shard glass observed in white bentonite that form interlayers with bitumen (Fig. 9c). Carbon in organic material with brown color are visible in polished-samples, too (Fig. 9d). 


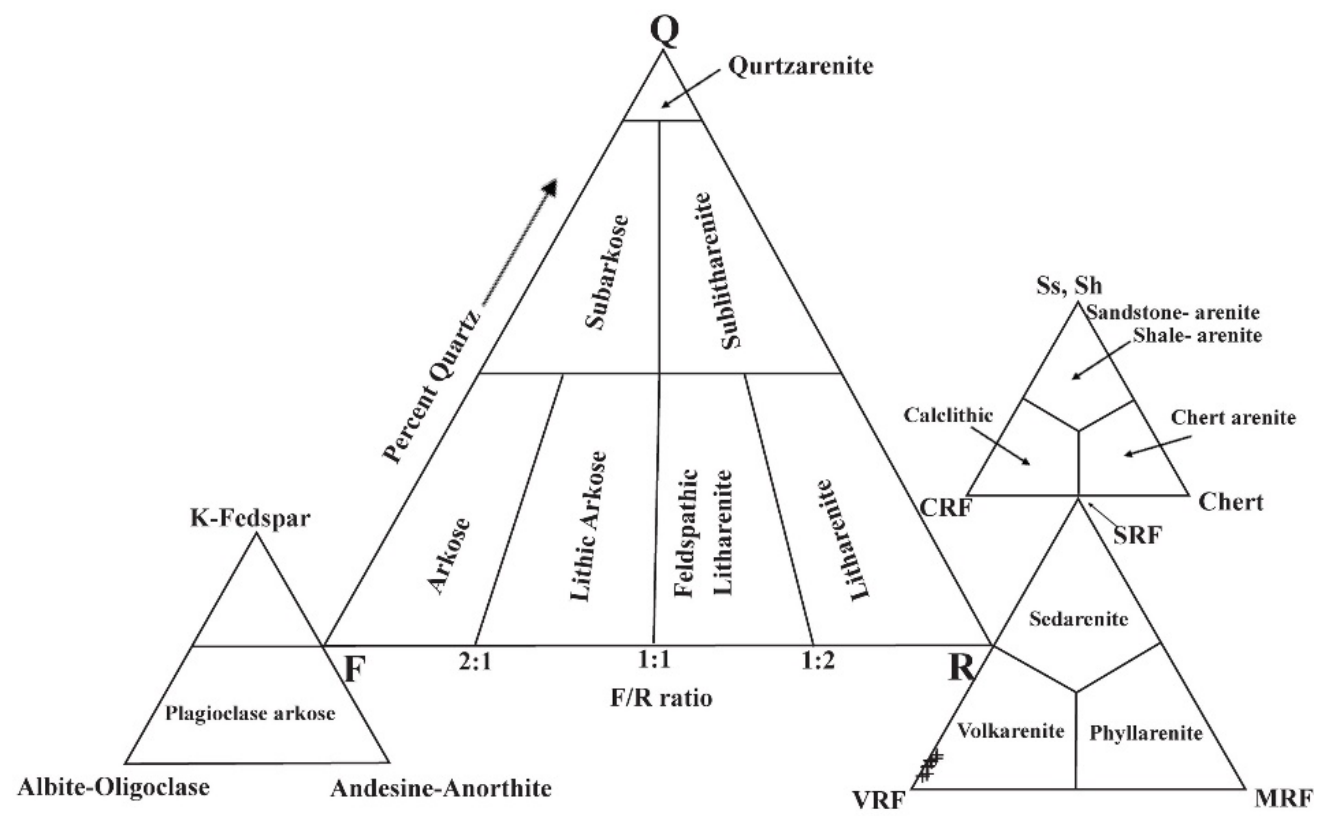

Fig. 8 Classification of sandstone by Folk (1974). As seen, selected Samples plot in volcanic arenite field.

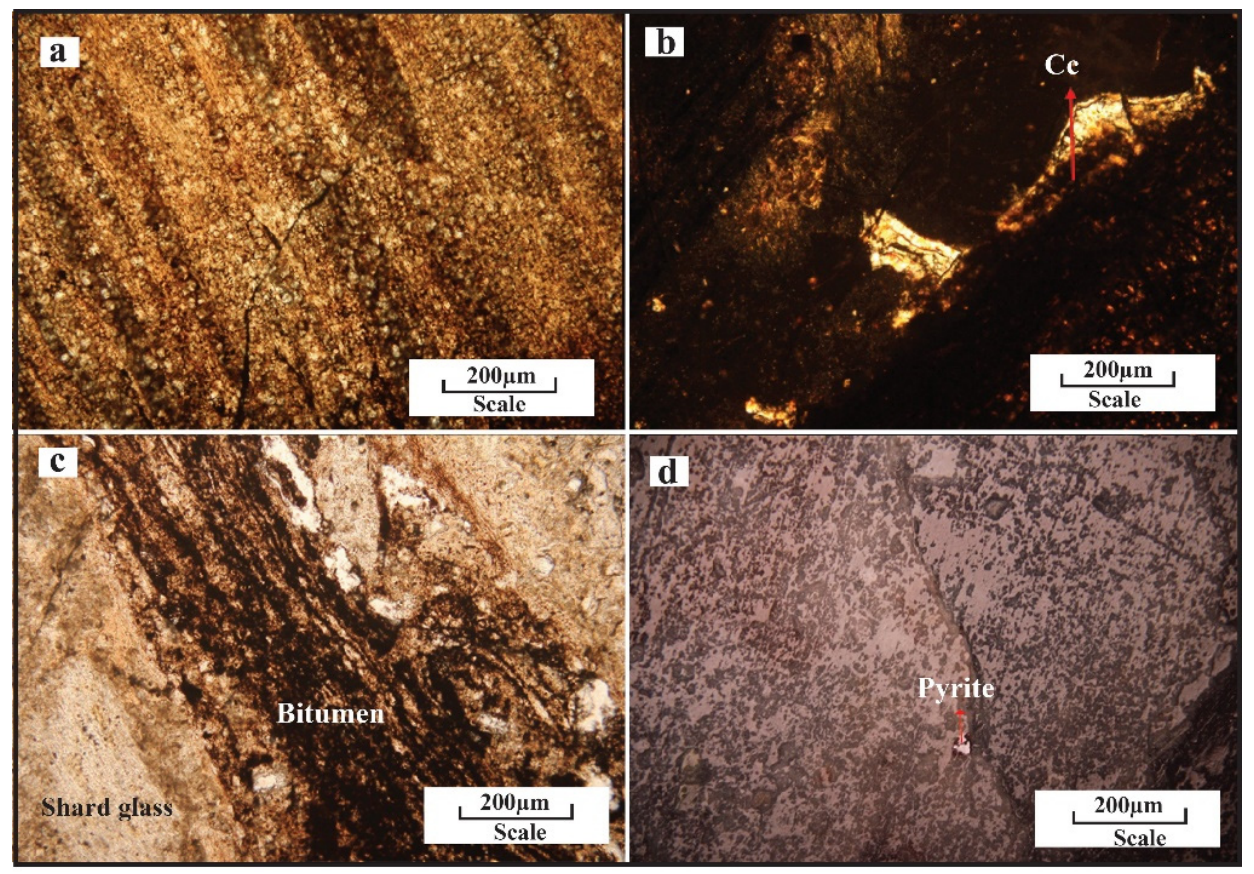

Fig. 9 a) deformation in wood texture because of tectonic pressure (XPL), b) formation of Chalcedony in open space filling of wood texture (XPL), c) alternation of white bentonite layers containing shard glass with carbon bearing layers (PPL), d) carbon with brown colour that associated by sporadic pyrite.

\subsection{XRD STUDY}

To detect types of clay minerals, two samples are studied in three conditions including: air-dried, heated at $550^{\circ} \mathrm{C}$ and treated with ethylene glycol (Figs. 10a and $\mathrm{b})$. At first, the particles with size below $2 \mu \mathrm{m}$ separated. These selected sections dispended into solution for 10 hours and finally were poured into the glass to be prepared directed sediment. In this way, different types of clay minerals are recognizable after using the X-ray. With heating clay samples at 80 to $90{ }^{\circ} \mathrm{C}$, the surface water begins to release in early stage. With increasing of temperature up to 100 or $200{ }^{\circ} \mathrm{C}$, bonded water exited from the clay structure. These crystalline water molecules located between smectite layers leave the structure of clay minerals at $500-550{ }^{\circ} \mathrm{C}$ in final stage. This water with $\mathrm{OH}$ - form located within smectite layers by strong bonds. The heating process lead to mass loss of clay samples. Then, the samples exposed to ethylene glycol for 24 hours. For dissolved sample, $\mathrm{d}_{(001)}$-spacing increased more than $4 \mathrm{~A}^{\circ}$, so they considered as expansible clay. 

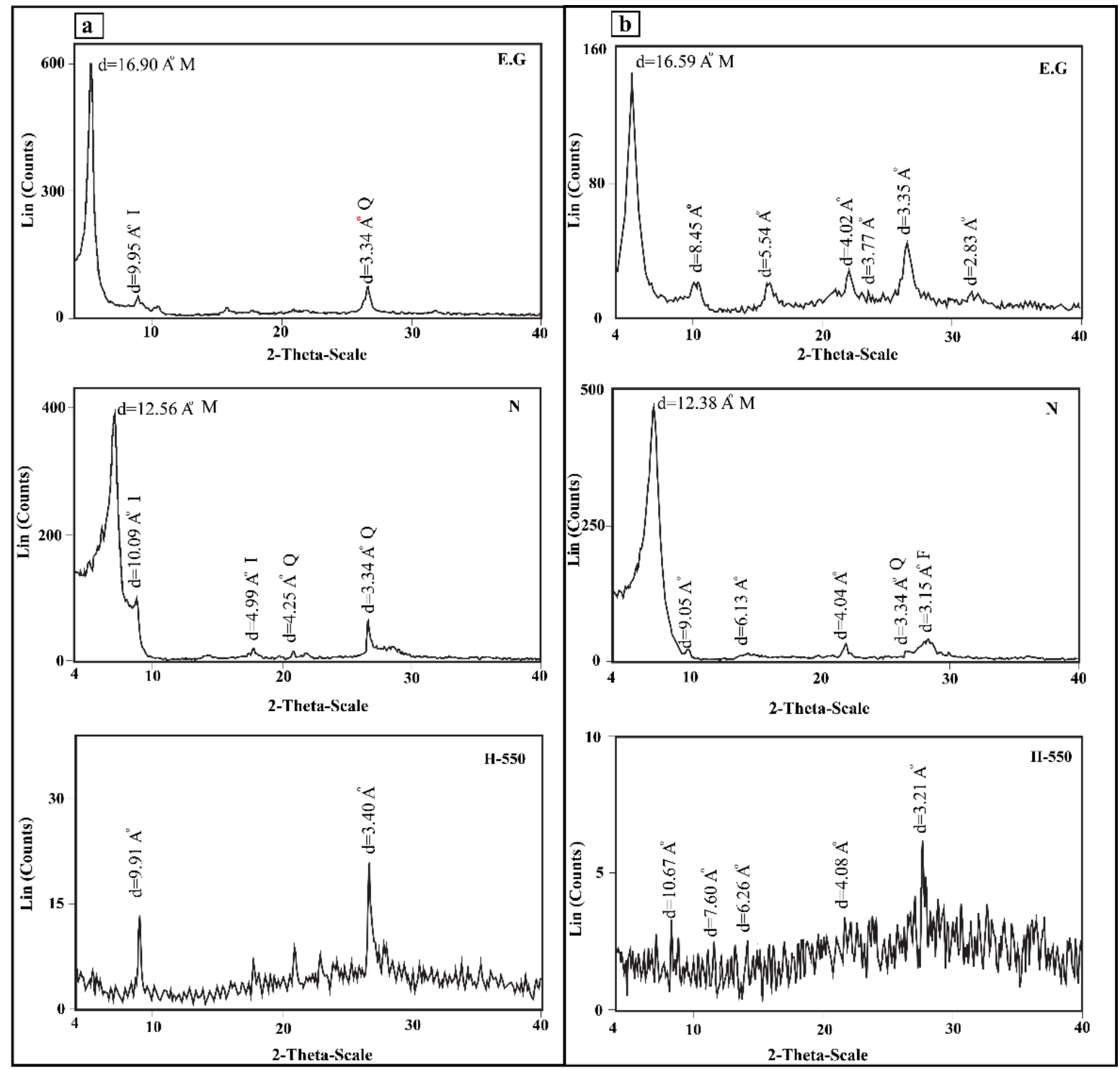

M=Mntmorillonite, $Q=$ Quartz, l=Illite, F=Feldspar

Fig. 10 Comparison of XRD diagrams for clay minerals in a) white and b) cream bentonites in three conditions: Air-dried, treated in ethylene glycol and heated at $550{ }^{\circ} \mathrm{C}$.

In sample-1, $\mathrm{d}_{(001)}$-spacing of montmorillonite in normal condition is $12.56 \mathrm{~A}^{\circ}$. This space increased by addition of ethylene glycol up to $16.9 \mathrm{~A}^{\circ}$. Putting the samples in oven and heating, this reflection decreases to $9.91 \mathrm{~A}^{\circ}$.

$\mathrm{d}_{(001)}$-spacing in sample-2 is measured $\sim 12.38 \mathrm{~A}^{\circ}$ in normal situation. This reflection by saturation of this sample with ethylene glycol increased to $16.59 \mathrm{~A}^{\circ}$ and ultimately by heating, decreased to $10.67 \mathrm{~A}^{\circ}$.

Although our accuracy in separation of particles was below $2 \mu \mathrm{m}$, small percentage of fine-grained quartz and broken feldspars stayed in prepared samples. Quartz have reflection in 4.25 and $3.34 \mathrm{~A}^{\circ}$ and feldspar have reflection in $3.18 \mathrm{~A}^{\circ}$. The results of XRD study indicated that montmorillonite, illite, montmorillonite-illite, nontronite and saponite constituted the clay minerals that accompanied by zeolite phases such as clinoptilolite and heulandite. Other resistant magmatic minerals such as anorthite, albite, sanidine, orthoclase and quartz with calcite remained in the bentonites (Figs. 11a and b). The montmorillonite coexists with illite and they have similar structures. In marine environment, montmorillonite easily convert to illite by increasing the temperature and burial depth (Mason and Moore, 1982). Inoue et al. (1992) indicated that the formation of illite-smectite minerals in hydrothermal systems is basically identical to that which occurs in diagenetic environments, i.e., that is due to a consecutive reaction from an early-formed smectite to illite through illitesmectite.

\subsection{MINERAL CHEMISTRY OF SMECTITE}

In order to calculate the structural formula (stoichiometric) for smectites, the white bentonite samples after powdering and passing through sieve 230 mesh (separated the particles below $75 \mu \mathrm{m}$ ), the samples are ready for SEM-EDS analyses. The results 

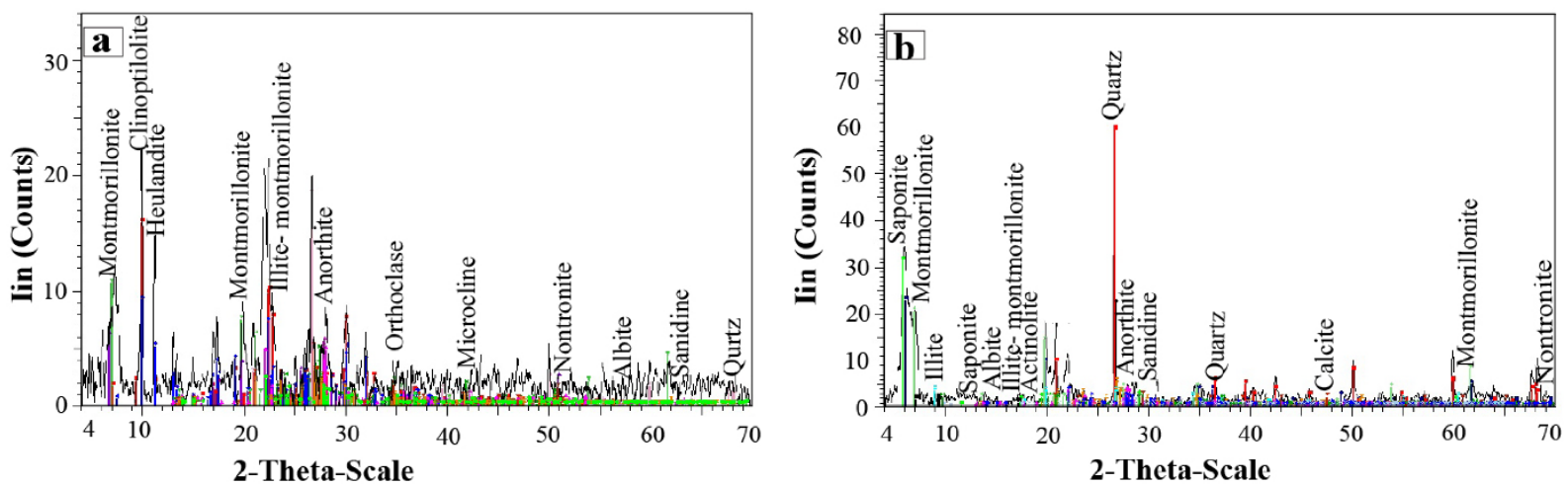

Fig. 11 XRD patterns of a) white and b) cream bentonite, respectively.

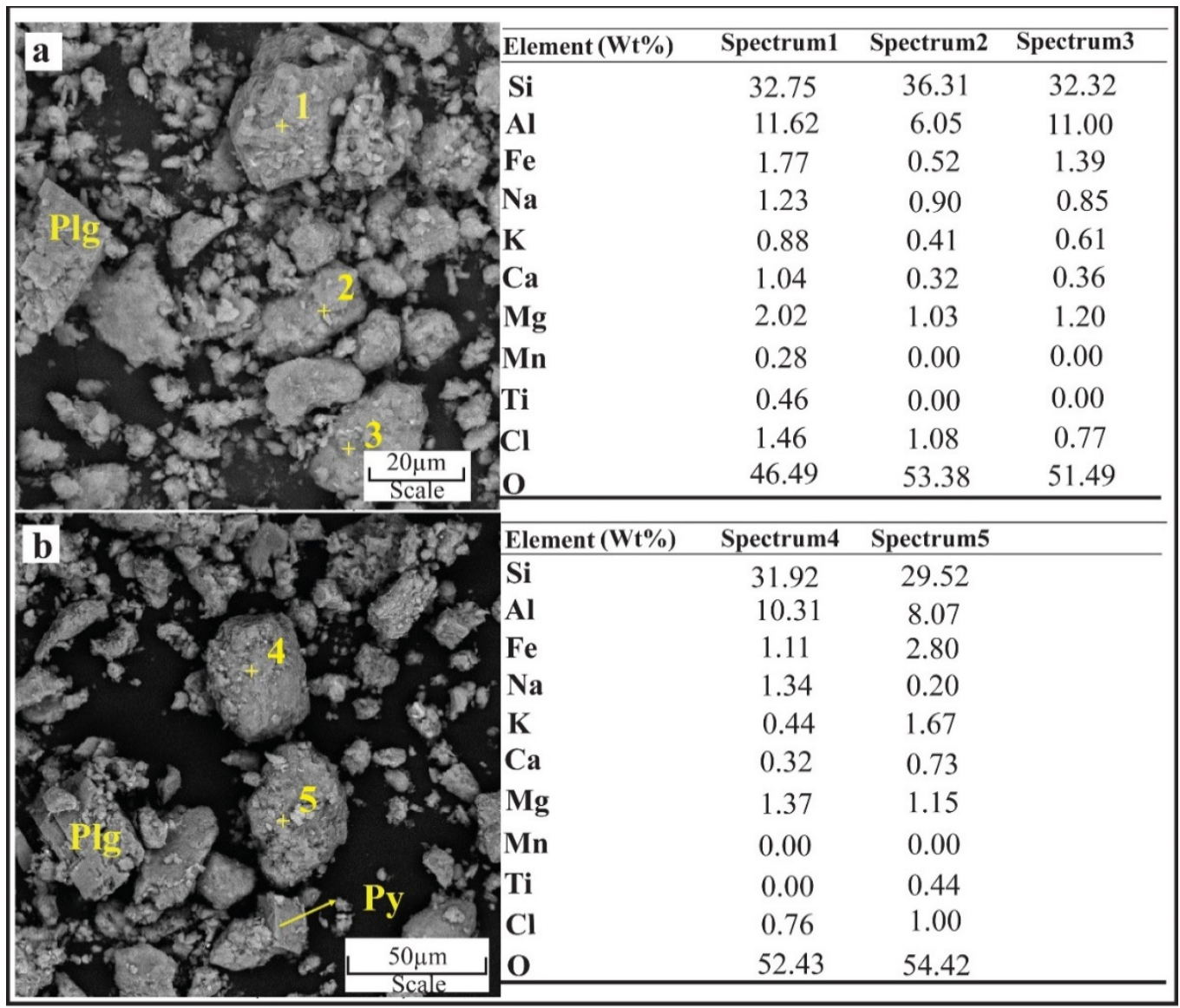

Fig. 12 SEM images of clay minerals (particles with size below $75 \mu \mathrm{m}$ ) that show the analyzed points and their results. Some pyrite and fine-grained plagioclase are mixing with clay minerals.

of 5 points in this sample are presented in Figure 12. Study of provided photos, proved that amount of broken plagioclase and cubic pyrite coexist with clays and in practice, the full separation of them is impossible. According to chemical analysis, based on clay fractions $(<2 \mu \mathrm{m})$, the empty sites in the tetrahedral positions are filled with $\mathrm{Al}$ to make $\mathrm{Si}+\mathrm{Al}$ $=4$. The remaining $\mathrm{Al}, \mathrm{Mg}$ and $\mathrm{Fe}$ are assigned to octahedral sites. Finally, $\mathrm{Ca}, \mathrm{Na}$ and $\mathrm{K}$ are assigned to exchangeable sites (Christidis, 2008).

The results of structural formulae calculated on the basis of 11 oxygene atoms (Christidis, 2008) are provided in Table 1 . As you see, amount of $\mathrm{Na}$ in clay structure is more than $\mathrm{Ca}$ and $\mathrm{K}$; hence, they can be classified as Wyoming-type bentonite (Christidis, 2008). The average chemical composition for smectites of Mollaahmad Pass is:

$$
\begin{gathered}
\left(\mathrm{Ca}_{0.0501} \mathrm{Na}_{0.1422} \mathrm{~K}_{0.0771}\right)\left(\mathrm{Al}_{1.2774}\right. \\
\left.\mathrm{Fe}_{0.1015} \mathrm{Mg}_{0.2036} \mathrm{Ti}_{0.0140} \mathrm{Mn}_{0.0035}\right)\left(\mathrm{Si}_{4.000} \mathrm{O}_{10}\right)(\mathrm{OH})_{2}
\end{gathered}
$$

In this composition, the aluminum in octahedral site replaced by mafic elements such as $\mathrm{Fe}, \mathrm{Ti}, \mathrm{Mg}$ and Mn (Table 2) so we conclude that the primary chemical composition of source materials (parent volcanic fragments) is mostly intermediate to mafic. As mentioned above, the mineralogical investigations confirmed this subject, too. 
Table 1 Stoichiometric coefficient values calculated based on EDS analyses and 11 oxygen (Christidis, 2008).

\begin{tabular}{lccccc}
\hline & Spectra 1 & Spectra 2 & Spectra 3 & Spectra 4 & \multicolumn{1}{c}{ Spectra 5 } \\
\hline $\mathrm{Na}$ & 0.183892 & 0.133862 & 0.142858 & 0.215278 & 0.03494 \\
$\mathrm{Mg}$ & 0.285801 & 0.178844 & 0.154723 & 0.208291 & 0.190153 \\
$\mathrm{Al}(\mathrm{VI})$ & 1.48015 & 1.475957 & 0.818201 & 1.411223 & 1.20134 \\
$\mathrm{Si}$ & 4.012349 & 4.170998 & 4.723005 & 4.202306 & 4.226651 \\
$\mathrm{~K}$ & 0.077417 & 0.056528 & 0.038295 & 0.041595 & 0.171696 \\
$\mathrm{Ca}$ & 0.089255 & 0.032545 & 0.029158 & 0.029511 & 0.073217 \\
$\mathrm{Ti}$ & 0.033045 & 0.0000 & 0.0000 & 0.0000 & 0.03694 \\
$\mathrm{Mn}$ & 0.017531 & 0.0000 & 0.0000 & 0.0000 & 0.0000 \\
$\mathrm{Fe}^{3+}$ & 0.108906 & 0.09009 & 0.033969 & 0.07339 & 0.201339 \\
\hline
\end{tabular}

Table 2 The chemical composition of smectite in five points of study area.

\begin{tabular}{cc}
\hline Point of analyse & Structural formula \\
\hline $\mathrm{A}$ & $\left(\mathrm{Ca}{ }_{0.082} \mathrm{Na}_{0.1839} \mathrm{~K}_{0.774}\right)\left(\mathrm{Al}_{1.4801} \mathrm{Fe}_{0.1089} \mathrm{Mg}_{0.2857} \mathrm{Ti}_{0.0330} \mathrm{Mn}_{0.0175}\right)\left(\mathrm{Si}_{4.000} \mathrm{O}_{10}\right)(\mathrm{OH})_{2}$ \\
$\mathrm{~B}$ & $\left(\mathrm{Ca}_{0.0325} \mathrm{Na}_{0.1339} \mathrm{~K}_{0.0565}\right)\left(\mathrm{Al}_{0.4759} \mathrm{Fe}_{0.0901} \mathrm{Mg}_{0.1778}\right)\left(\mathrm{Si}_{4.000} \mathrm{O}_{10}\right)(\mathrm{OH})_{2}$ \\
$\mathrm{C}$ & $\left(\mathrm{Ca}_{0.0291} \mathrm{Na}_{0.1428} \mathrm{~K}_{0.0382}\right)\left(\mathrm{Al}_{0.8182} \mathrm{Fe}_{0.0340} \mathrm{Mg}_{0.1547}\right)\left(\mathrm{Si}_{4.000} \mathrm{O}_{10}\right)(\mathrm{OH})_{2}$ \\
$\mathrm{D}$ & $\left(\mathrm{Ca}_{0.0295} \mathrm{Na}_{0.2153} \mathrm{~K}_{0.0416}\right)\left(\mathrm{Al}_{1.4112} \mathrm{Fe}_{0.0734} \mathrm{Mg}_{0.2083}\right)\left(\mathrm{Si}_{4.000} \mathrm{O}_{10}\right)(\mathrm{OH})_{2}$ \\
$\mathrm{E}$ & $\left(\mathrm{Ca}_{0.0732} \mathrm{Na}_{0.035} \mathrm{~K}_{0.1717}\right)\left(\mathrm{Al}_{1.2013} \mathrm{Fe}_{0.2013} \mathrm{Mg}_{0.1901} \mathrm{Ti}_{0.0370}\right)\left(\mathrm{Si}_{4.000} \mathrm{O}_{10}\right)(\mathrm{OH})_{2}$ \\
\hline
\end{tabular}

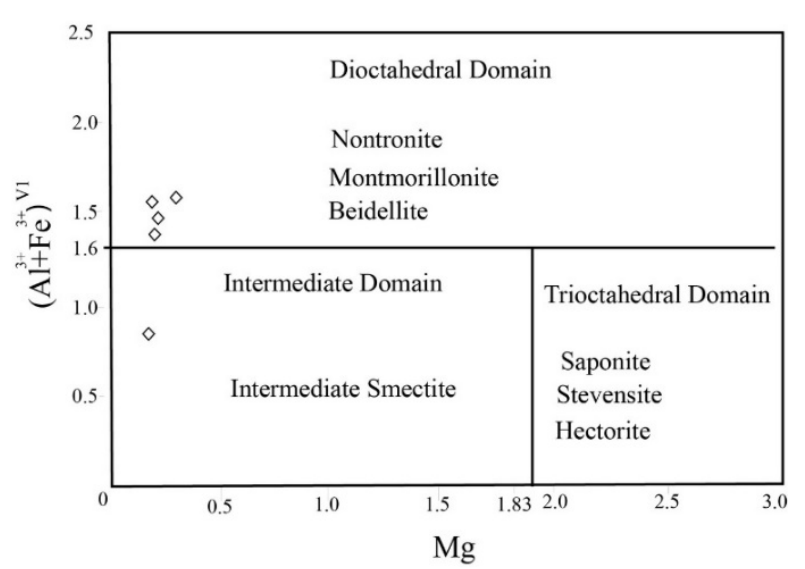

Fig. 13 The position of Mollaahmad Pass data points on bivariate $\mathrm{Mg}-\left(\mathrm{Al}^{+}+\mathrm{Fe}^{3+}\right)^{\mathrm{VI}}$ chart (Weaver and Pollard, 1973) for classification of dioctahedral from trioctahedral smectite.

For determining dioctahedral from trioctahedral cation, used two variable chart $\mathrm{Mg}-\left(\mathrm{Al}^{3+}+\mathrm{Fe}^{3+}\right)^{\mathrm{VI}}$ (Weaver and Polard, 1973) (Fig. 13). According to this chart, our data are plotted in intermediate to dioctahedral field and can be classified as expansible minerals.

In the intermediate to alkaline types of alteration, dioctahedral clays such as montmorillonite, interstratified illite/smectite, and illite are dominate in rocks, which were originally felsic (Inoue, 1995). This preferential occurrence may be in part due to fact that felsic rocks contain more $\mathrm{Na}$ and $\mathrm{K}$ and less $\mathrm{Mg}$ and $\mathrm{Fe}$ than due mafic rocks, also Na-rich plagioclase and glass are replaced by dioctahedral clays in these types of alteration. Mafic rocks such as basalt are altered to trioctahedral clays including saponite, chlorite/smectite and chlorite (Inoue, 1995). In Mollaahmad Pass bentonite deposit, both saponite and montmorillonite are identified in X-ray diffraction of samples. It may be related to presence of felsic, intermediate and mafic volcanic rock fragments in parent rock.

The Al-Al-, Mg-Al-Fe-Al, ternary plots of Güven (1988) can be useful for determining various kinds of bentonites based on octahedral cation. Our data plot in beidellite field (BI) (Fig. 14). The stability fields of smectite and Na-beidellite display that there is no solid solution between two phases. However, Christidis and Dunhom (1996) reported that there is relationship between Cheto-type smectite and biedelite-bearing series. They further illustrated that great substitution of $\mathrm{Al}$ for $\mathrm{Si}$ in biedelite-bearing series, more interlayers of $\mathrm{Ca}$ than $\mathrm{Na}$ can be expected to present in crystal lattice for change balance reasons. Then, the conversion of biedelite-bearing series to Wyoming type montmorillonite, always occurs in presence of Cheto-type smectites. The absence of Cheto-type smectites in this study could be related to excess of silicate that generated from destruction of reaction phase by alteration solutions. Because of incomplete separation of quartz from smectite in structural formula, the silica in the tetrahedral site will increase, therefore more aluminum located in octahedral site. Consequently, the calculated composition will be changed from Wyoming montmorillonite to beidellite type. 


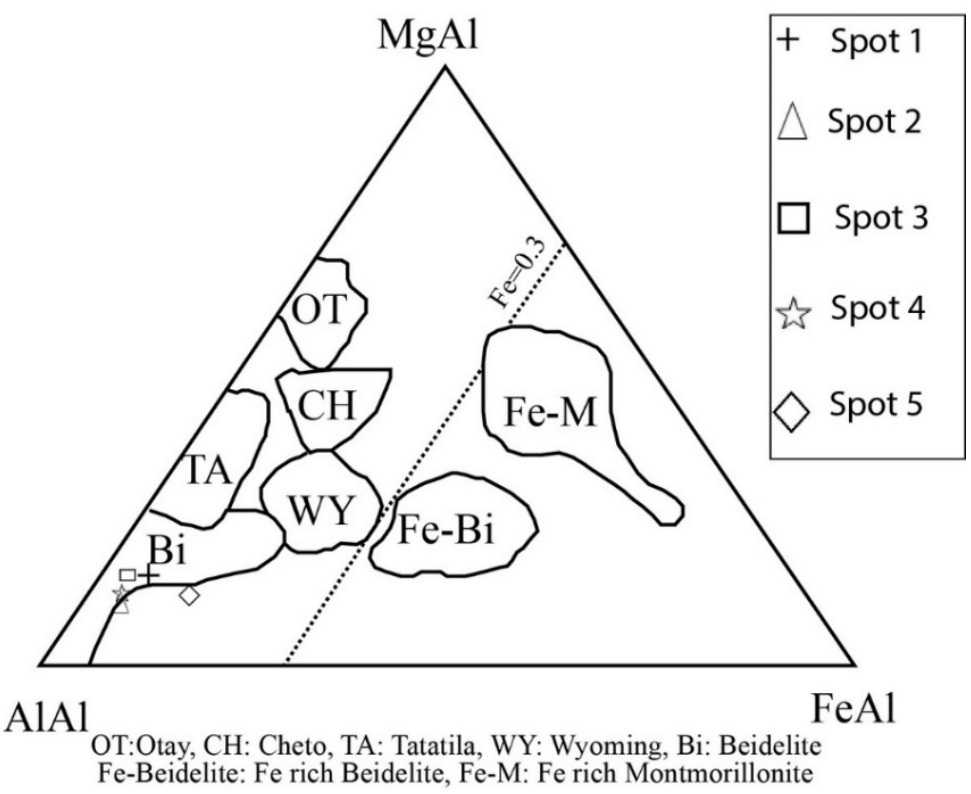

Fig. 14 The position of Mollaahmad Pass data points on ternary plot (Guven, 1988) differentiating between the various types of bentonites based on cations.

\subsection{CHEMISTRY OF ORGANIC MATERIAL}

The chemical composition of one selected sample of organic material in seven points has been determined by SEM-EDS analysis (Fig. 15). Deformation and the sporadic fine-grained pyrite can be examined in provided pictures. In this regard, the $\mathrm{S}$ (below $0.06 \mathrm{wt} \%$ ) and $\mathrm{C}$ (in the range of 0.84 to $3.43 \mathrm{wt} \%$ ) have been detected in their composition (Table 3). Exiting of $\mathrm{Si}$ and $\mathrm{O}$ due to presence of replaced quartz in wood texture and the sodium and aluminum reflection are related to clay minerals.

\subsection{THE ESTIMATION OF PHYSICO-CHEMICAL CONDITIONS}

The mineralogical investigation indicates that the major part of pumice debris, shard glass and plagioclase in the volcanic arenites, polymictic conglomerate and altered tuffs are converted into clay minerals.

According to the following equation, the amount of silica forms with montmorillonite during destruction of K-feldspars and albite (Brown et al., 1988).

$$
\begin{aligned}
& \mathrm{KAlSi}_{3} \mathrm{O}_{8}+2 \mathrm{H}^{+} \leftrightarrow(\mathrm{Al}, \mathrm{Mg}, \mathrm{Fe})_{2}(\mathrm{Si}, \mathrm{Al})_{4} \mathrm{O}_{10}(\mathrm{OH})_{2}+ \\
& +\mathrm{SiO}_{2}+\mathrm{K}^{+} \\
& \text {(K-feldspar) } \\
& \text { (Montmorillonite) } \\
& \mathrm{NaAlSi}_{3} \mathrm{O}_{8}+\mathrm{H}^{+} \leftrightarrow(\mathrm{Al}, \mathrm{Mg}, \mathrm{Fe})_{2}(\mathrm{Si}, \mathrm{Al})_{4} \mathrm{O}_{10}(\mathrm{OH})_{2}+ \\
& +\mathrm{SiO}_{2}+\mathrm{Na}^{+} \\
& \text {(Albite) }
\end{aligned}
$$

Because, the shard glass has high interaction, so they can converted easily to clay minerals in aqueous system (Bohor and Triplehorn, 1993):

Volcanic glass $+\mathrm{H}_{2} \mathrm{O} \rightarrow$ hydrated Al-silicate gel + montmorillonite + hydrated silica $+\mathrm{H}_{2} \mathrm{O}+$ cations

Alteration of volcanic glass may take place through weathering, gas phase crystallization, burial diagenesis, contact metamorphism, hydrothermal activity, percolating ground water and in alkaline lakes or the sea floor, in marine sediments (Iijima, 1980; Cas and Wright, 1988).

Montmorillonite is a stable mineral in about $\mathrm{pH}$ 7. Zeolite stability is strongly dependent upon silica activity in the fluid phase (Coombs et al., 1959). The $\mathrm{Si} / \mathrm{Al}$ ratio of zeolites has also been observed to decrease with increasing $\mathrm{pH}$ in natural systems

Table. 3 The results of EDS analyses in seven points of organic materials.

\begin{tabular}{lcccccc}
\hline & $\mathbf{C}$ & $\mathbf{S}$ & $\mathbf{O}$ & $\mathbf{N a}$ & $\mathbf{A l}$ & Si \\
\hline Spectra A & 3.43 & 0.03 & 53.25 & - & 0.72 & 37.14 \\
Spectra B & 1.41 & - & 57.00 & - & 0.52 & 37.93 \\
Spectra C & 1.60 & 0.06 & 50.31 & 2.88 & 4.75 & 34.35 \\
Spectra D & 0.84 & 0.01 & 45.45 & - & 0.22 & 41.62 \\
Spectra E & 2.29 & - & 45.96 & - & - & 48.01 \\
Spectra F & 2.80 & - & 45.46 & - & 1.13 & 45.19 \\
Spectra G & 1.63 & - & 46.77 & - & - & 51.09 \\
\hline
\end{tabular}




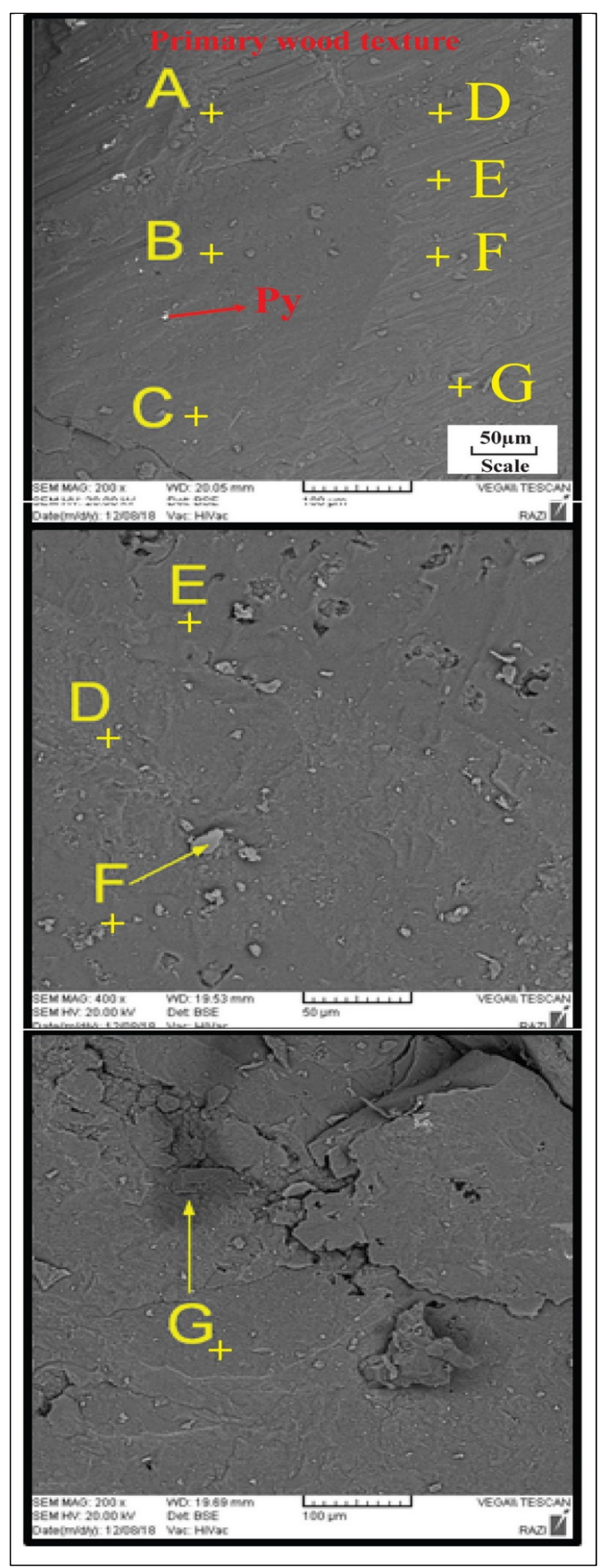

Fig. 15 SEM images of organic material with analyses points. The fine-grained pyrite has been observed.

(Mariner and Surdam, 1970). Silica-rich zeolites such as mordenite and clinoptilolite are typical of the alteration of volcanic glass in marine and fresh water environments (pH 7-9) (Savage et al., 2007). Whereas less siliceous zeolites such as erionite occur in saline, alkaline lakes (pH 9-10.5) (Savage et al., 2007). It seems that Mollaahmad Pass bentonite deposite formed approximately in $\mathrm{pH}$ 7-9.

The resultant silica in right side of equation may be crystalized into crystobalite and quartz. The fluids with low $\mathrm{pH}$ create two types of mineral phases: without silica (gibbsite, bohmite and diaspore) and low silica (muscovite, illite and kaolinite) minerals (Garrels, 1984). Mutually, high pH fluids lead to high silica minerals (pyrophyllite, smectite and feldspars). With increasing activity of $\mathrm{K}^{+} / \mathrm{H}^{+}$, formation of some minerals such as illite, muscovite and feldspars will occur (Garrels, 1984) (Fig. 16).

In addition, with increasing temperature, kaolinite converted to pyrophyllite and andalusite (Manning, 1995) (Fig. 17). Alteration of source materials into smectites and zeolites occurs in two steps (Velde, 1992) (Fig. 18):

1 Firstly, the solution of volcanic glass and crystallization of crystobalite and smectite with low ratio of alkali/ $\mathrm{H}^{+}$occur.

2 Secondly, the alkaline cations, ratio of alkali/ $\mathrm{H}^{+}$ and $\mathrm{pH}$ will increase, so in this condition's zeolites with high proportion of $\mathrm{Si} / \mathrm{Al}$ are precipitated. By increasing of alteration intensity, zeolite with high ratio of $\mathrm{Al} / \mathrm{Si}$ will occur. In addition, feldspars in high salty fluids are result of final production of alteration.

Generally, the alteration of shard glass is a common process that lead to occurrence of smectite and zeolite in most bentonite deposits (Christidis et al., 1995; Hay and Guldman., 1987; Senkayi et al., 1984). It is noteworthy that zeolites, as well as clay minerals characterize the mineral assemblages of alteration zones in the $\mathrm{Na}, \mathrm{Ca}, \mathrm{K}$ and $\mathrm{Ca}-\mathrm{Mg}$ alteration series (Inoue, 1995). In $\mathrm{Ca}$ and $\mathrm{Ca}-\mathrm{Mg}$ series of alteration, heulandite occur in most rock. Clinoptilolite is common in $\mathrm{Na}$ and $\mathrm{K}$ series (Inoue, 1995).

\subsection{GEOCHEMISTRY}

The results of geochemical analyses are listed in Tables 4 and 5. Common bivariate plot of major elements $\left(\mathrm{Na}_{2} \mathrm{O}+\mathrm{K}_{2} \mathrm{O}-\mathrm{SiO}_{2}\right)(\mathrm{Cox}$ et al., 1979) is used to determine the composition of the parent rock. With the use of TAS diagram the fresh volcanic fragment samples plot in the andesite-dacite field (Fig. 19 a) for determining the magmatic series the AFM diagram used (Irvin and Baraga, 1971). Our samples plot in the calc-alkaline field and some of them are near calkalkaline - tholeiitic boundary (Fig. 19 b). By using of immobile element such as $\mathrm{Ti}, \mathrm{Y}, \mathrm{Zr}$ and $\mathrm{Nb}$, the Mollaahmad Pass samples plot in the rhyodacite / dacite, andesite, trachyandesite and sub-alkaline basalts field of the $\mathrm{Zr} / \mathrm{Ti}$ versus $\mathrm{Nb} / \mathrm{Y}$ bivariate plot of Winchester and Floyd (1977), the primary composition protoliths of the bentonite illustrated in Figure 20. 


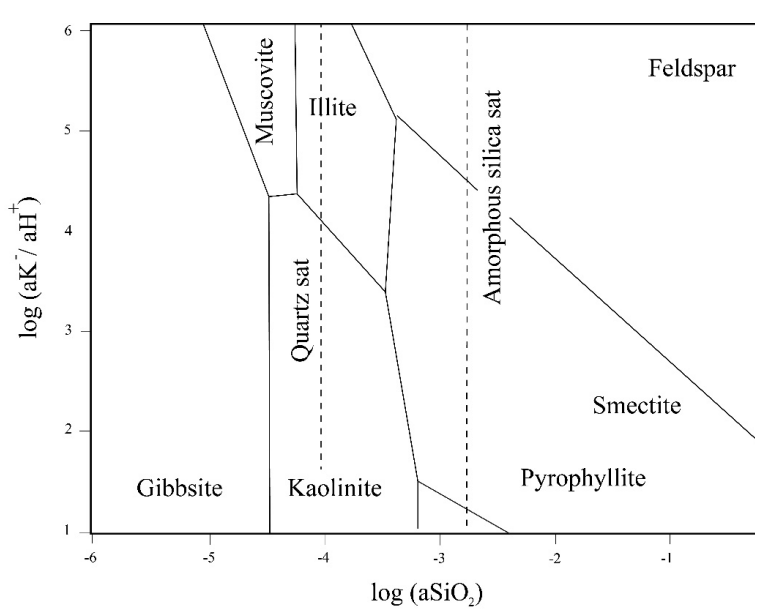

Fig. 16 Field stability of smectite, kaolinite, pyrophyllite, illite, K.fld in bivariate $\log$ $\mathrm{a}(\mathrm{SiO} 2)-\log \mathrm{a}\left(\mathrm{K}^{+} / \mathrm{H}^{+}\right)$plot (Garrels, 1984).

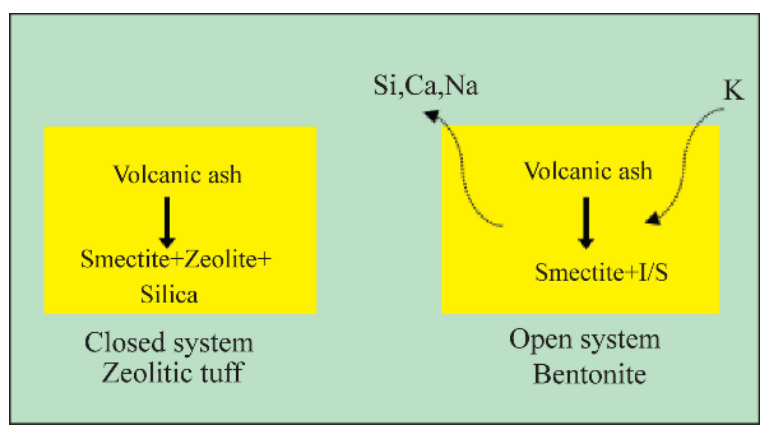

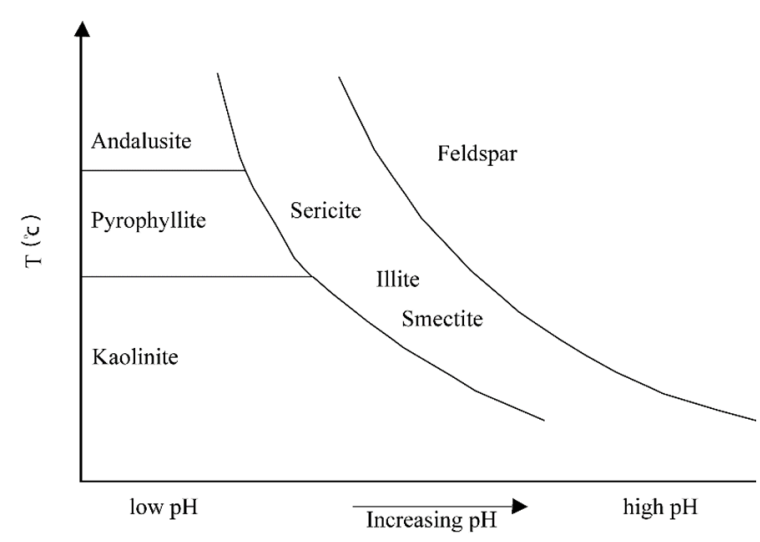

Fig. 17 The field stability of smectite, illite, Kfeldspar, kaolinite, pyrophyllite and andalusite in bivariate $\mathrm{T}-\mathrm{pH}$ diagram (Manning, 1995).

Fig. 18 Schematic model of conversion of acidic volcanic material into zeolitic tuff, in closed system and smectite or illite, in open system that chemical elements can be get in or get out (Velde, 1992).

Table 4 Concentration of major and minor oxides by XRF in selected samples of fresh volcanic fragments. Also the detection limits for the elements are listed, nd= not detected.

\begin{tabular}{|c|c|c|c|c|c|c|c|c|c|c|c|c|c|c|c|}
\hline $\begin{array}{l}\text { Element } \\
\text { Unit }\end{array}$ & $\begin{array}{l}\mathrm{SiO}_{2} \\
\%\end{array}$ & $\begin{array}{l}\mathbf{A l}_{2} \mathbf{O}_{3} \\
\%\end{array}$ & $\begin{array}{l}\mathrm{BaO} \\
\%\end{array}$ & $\begin{array}{l}\mathrm{CaO} \\
\%\end{array}$ & $\begin{array}{l}\mathrm{Fe}_{2} \mathrm{O}_{3} \\
\%\end{array}$ & $\begin{array}{l}\mathbf{K}_{2} \mathbf{O} \\
\%\end{array}$ & $\begin{array}{l}\text { MgO } \\
\%\end{array}$ & $\begin{array}{l}\text { MnO } \\
\%\end{array}$ & $\begin{array}{l}\mathrm{Na}_{2} \mathbf{O} \\
\%\end{array}$ & $\begin{array}{l}\mathbf{P}_{2} \mathbf{O}_{5} \\
\%\end{array}$ & $\begin{array}{l}\mathrm{SO}_{3} \\
\%\end{array}$ & $\begin{array}{l}\mathbf{T i O}_{2} \\
\%\end{array}$ & $\begin{array}{l}\mathrm{Cr}_{2} \mathrm{O}_{3} \\
\%\end{array}$ & $\begin{array}{l}\text { LOI } \\
\%\end{array}$ & Sum \\
\hline DL & 0.05 & 0.05 & 0.05 & 0.05 & 0.05 & 0.05 & 0.05 & 0.05 & 0.05 & 0.05 & 0.05 & 0.05 & 0.05 & 0.05 & \\
\hline T-1 & 63.36 & 15.97 & 0.10 & 6.06 & 3.39 & 2.63 & 0.60 & 0.08 & 3.86 & 0.23 & 0.07 & 0.47 & $\mathrm{Nd}$ & 3.12 & 99.94 \\
\hline A-2 & 64.38 & 16.71 & 0.29 & 4.44 & 4.03 & 3.01 & 0.42 & nd & 3.09 & 0.23 & 0.15 & 0.71 & $\mathrm{Nd}$ & 2.55 & 100.01 \\
\hline A-3 & 64.63 & 16.58 & 0.3 & 4.39 & 4.1 & 2.9 & 0.43 & nd & 3.03 & 0.2 & 0.14 & 0.71 & $\mathrm{Nd}$ & 2.57 & 99.98 \\
\hline T-2 & 62.56 & 16.71 & 0.09 & 6.02 & 3.49 & 2.47 & 0.64 & 0.08 & 3.98 & 0.25 & 0.07 & 0.48 & $\mathrm{Nd}$ & 3.16 & 100 \\
\hline T-3 & 62.74 & 16.55 & 0.1 & 5.99 & 3.52 & 2.46 & 0.62 & 0.08 & 4 & 0.23 & 0.05 & 0.47 & $\mathrm{Nd}$ & 3.12 & 99.93 \\
\hline A-1 & 64.50 & 15.91 & 0.29 & 4.44 & 3.95 & 3.07 & 0.41 & nd & 2.83 & 0.22 & 0.16 & 0.67 & 0.07 & 3.48 & 100.00 \\
\hline
\end{tabular}

\subsubsection{BEHAVIOUR OF ELEMENTS DURING BENTONITIZATION}

In order to display the behavior of elements during bentonitization processes, the normalized diagrams of major, minor and rare earth elements to UCC (Taylor, 1964) and chondrite were used (Taylor and McLennan, 1985) (Figs. 21, 22 and 23).

The results show that the major, minor and REE have four different modes of behavior. The first mode belongs to $\mathrm{Hf}$ and $\mathrm{Zr}$, which behave relatively immobile in the system. The distribution mode of these elements suggests the aqueous conditions allowed these elements to be residually concentrated in bentonites (Calagari et al., 2016). The second mode is related to elements such as $\mathrm{Cr}, \mathrm{Sb}, \mathrm{Se}$ and REEs, that enriched during bentonitization process. The third mode includes elements such as $\mathrm{Si}, \mathrm{Al}, \mathrm{Ca}, \mathrm{Fe}, \mathrm{K}, \mathrm{Mg}$, $\mathrm{Na}, \mathrm{Ag}, \mathrm{As}, \mathrm{Ba}, \mathrm{Cd}, \mathrm{Cs}, \mathrm{Li}, \mathrm{Mo}, \mathrm{Ni}, \mathrm{Pb}, \mathrm{Rb}, \mathrm{Zn}, \mathrm{Sn}$, $\mathrm{Sr}, \mathrm{Th}, \mathrm{Tl}, \mathrm{U}$ and $\mathrm{W}$ which display two opposite trends of enrichment-depletion. Fourth mode pertains to elements such as Ta, P, Ti, Be, Co, Cu, Nb, Sc, V and $\mathrm{Y}$, which undergo depletion. Depletion of $\mathrm{K}_{2} \mathrm{O}$ and $\mathrm{SiO}_{2}$ can be related to alteration of feldspars and transportation of these elements to solutions in water rock interaction system (Munch et al., 1996).

Depletion of $\mathrm{Ca}$ in some samples due to its high solubility in alteration environment and its enrichment may be related to the presence in interlayer sites of 
Table 5 Concentration of major, minor, trace and REEs along with LOI for various types of whole rock bentonite, fresh volcanic fragments and silicic samples. Moreover, the detection limits for the elements and the values of Eu and Ce anomalies by $(\mathrm{La} / \mathrm{Yb})_{\mathrm{N}},(\mathrm{Gd} / \mathrm{Yb})_{\mathrm{N}}$ and $(\mathrm{La} / \mathrm{Sm})_{\mathrm{N}}$ are listed, nd=not detected.

\begin{tabular}{|c|c|c|c|c|c|c|c|c|c|c|c|c|c|c|c|c|}
\hline Element & $\mathrm{SiO}_{2}$ & $\mathrm{Al}_{2} \mathbf{O}_{3}$ & $\mathrm{CaO}$ & $\mathrm{Fe}_{2} \mathrm{O}_{3}$ & $\mathbf{K}_{2} \mathbf{O}$ & MgO & MnO & $\mathrm{Na}_{2} \mathrm{O}$ & $\mathbf{P}_{2} \mathbf{O}_{5}$ & $\mathrm{TiO}_{2}$ & $\mathrm{Cr}_{2} \mathrm{O}_{3}$ & LOI & Sum & Ag & As & Ba \\
\hline Unit & $(\mathbf{w t} \%)$ & $(\mathbf{w t} \%)$ & $(\mathbf{w t} \%)$ & (wt\%) & $(\mathbf{w t} \%)$ & $(\mathbf{w t} \%)$ & wt\%) & $(\mathbf{w t} \%)$ & $(\mathbf{w t} \%)$ & (wt\%) & $(\mathbf{w t} \%)$ & $(\mathbf{w t} \%)$ & (wt\%) & ppm & ppm & ppm \\
\hline Detection limit & 0.05 & 0.05 & 0.05 & 0.05 & 0.05 & 0.05 & 0.05 & 0.05 & 0.05 & 0.05 & 0.05 & 0.05 & - & 0.1 & 0.1 & 1 \\
\hline A-1( Fresh Volcanic fragments) & 64.50 & 15.91 & 4.44 & 3.95 & 3.07 & 0.41 & 0.02 & 2.83 & 0.22 & 0.67 & 0.07 & 3.48 & 99.57 & 0.50 & 28.60 & 2667.00 \\
\hline B-1(Green bentonite) & 62.45 & 15.16 & 4.49 & 4.90 & 2.97 & 0.77 & 0.02 & 3.17 & 0.27 & 0.83 & 0.02 & 4.81 & 99.86 & 0.70 & 34.00 & 635.00 \\
\hline B-2 (White bentonite) & 66.47 & 13.21 & 2.29 & 1.73 & 0.85 & 1.88 & 0.02 & 2.26 & 0.06 & 0.23 & 0.02 & 10.98 & 100.00 & 0.10 & 6.00 & 255.00 \\
\hline B-3 (Yellow bentonite) & 60.03 & 10.77 & 12.49 & 2.91 & 1.26 & 0.70 & 0.25 & 1.41 & 0.06 & 0.18 & 0.02 & 9.89 & 99.97 & 0.10 & 22.60 & 394.00 \\
\hline B-4 (Red bentonite) & 59.05 & 11.53 & 11.73 & 2.89 & 1.43 & 0.99 & 0.16 & 1.77 & 0.05 & 0.23 & 0.02 & 10.07 & 99.92 & 0.20 & 14.30 & 341.00 \\
\hline B-5 (Low Pink bentonite) & 46.00 & 11.04 & 11.38 & 3.28 & 0.95 & 5.62 & 0.18 & 1.97 & 0.06 & 0.23 & 0.02 & 19.15 & 99.88 & 0.10 & 21.00 & 382.00 \\
\hline B-6 (Cream bentonite) & 51.41 & 11.37 & 16.84 & 2.97 & 1.40 & 0.62 & 0.10 & 1.87 & 0.10 & 0.21 & 0.02 & 13.02 & 99.93 & 0.10 & 27.20 & 370.00 \\
\hline B-7 (Gray bentonite) & 59.28 & 18.22 & 5.15 & 3.80 & 1.08 & 2.15 & 0.06 & 4.43 & 0.26 & 0.53 & 0.02 & 4.80 & 99.78 & 0.50 & 1.20 & 882.00 \\
\hline B-8 (Pink bentonite) & 64.61 & 10.17 & 4.44 & 2.18 & 0.89 & 2.27 & 0.05 & 2.54 & 0.07 & 0.19 & 0.02 & 12.59 & 100.02 & 0.10 & 9.40 & 88.00 \\
\hline C-1 (Grayish White bentonite) & 62.84 & 11.99 & 5.52 & 3.14 & 1.74 & 2.24 & 0.10 & 2.87 & 0.10 & 0.38 & 0.02 & 8.80 & 99.74 & $<0.10$ & 15.20 & 1513.00 \\
\hline S-1 (Silicic Samples) & 72.44 & 13.44 & 1.83 & 2.26 & 3.94 & 0.17 & 0.05 & 4.06 & 0.23 & 0.13 & 0.08 & 1.16 & 99.79 & 0.20 & 5.30 & 1256.00 \\
\hline T-1 (Fresh Volcanic fragments) & 63.36 & 15.97 & 6.06 & 3.39 & 2.63 & 0.60 & 0.08 & 3.86 & 0.23 & 0.47 & 0.02 & 3.12 & 99.79 & 0.40 & 5.70 & 894.00 \\
\hline Element & $\begin{array}{l}\mathbf{B e} \\
\end{array}$ & $\mathbf{C C d}$ & Co & $\mathbf{C r}$ & Cs & $\mathbf{C u}$ & Hff & 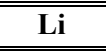 & Mo & $\mathbf{N b}$ & 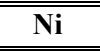 & 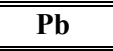 & Rb & 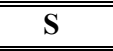 & 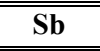 & $\begin{array}{l}\text { Sc } \\
\end{array}$ \\
\hline Unit & ppm & ppm & ppm & ppm & ppm & ppm & ppm & ppm & ppm & Ppm & ppm & ppm & ppm & ppm & ppm & ppm \\
\hline Detection limit & 0.2 & 0.1 & 1 & 1 & 0.5 & 1 & 0.5 & 1 & 0.1 & 1 & 1 & 1 & 1 & $\mathbf{5 0}$ & 0.5 & 0.5 \\
\hline A-1( Fresh Volcanic fragments) & 1.80 & 0.10 & 11.40 & 118.00 & 15.90 & 46.00 & 5.22 & 5.00 & 5.00 & 12.30 & 85.00 & 32.00 & 92.00 & 601.00 & 5.30 & 10.20 \\
\hline B-1(Green bentonite) & 2.20 & 0.20 & 12.00 & 116.00 & 19.50 & 44.00 & 5.12 & 10.00 & 4.40 & 12.40 & 78.00 & 30.00 & 119.00 & 289.00 & 3.10 & 15.20 \\
\hline B-2 (White bentonite) & 1.50 & 0.05 & 5.20 & 19.00 & 23.70 & 37.00 & 3.08 & 6.00 & 0.05 & 6.90 & 20.00 & 8.00 & 38 & 193.00 & 0.70 & 6.10 \\
\hline B-3 (Yellow bentonite) & 1.70 & 2.50 & 12.70 & 30.00 & 12.90 & 37.00 & 2.77 & 9.00 & 1.50 & 5.60 & 32.00 & 344.00 & 46.00 & 260.00 & 0.90 & 5.20 \\
\hline B-4 (Red bentonite) & 1.40 & 1.80 & 9.90 & 29.00 & 14.90 & 44.00 & 2.80 & 11.00 & 1.20 & 6.00 & 27.00 & 160.00 & 54.00 & 195.00 & 1.10 & 5.70 \\
\hline B-5 (Low Pink bentonite) & 1.20 & 0.20 & 9.70 & 29.00 & 17.10 & 14.00 & 2.64 & 6.00 & 0.50 & 6.10 & 25.00 & 12.00 & 35.00 & 525.00 & 1.10 & 5.80 \\
\hline B-6 (Cream bentonite) & 1.40 & 1.40 & 6.70 & 39.00 & 9.30 & 36.00 & 3.01 & 10.00 & 1.50 & 6.60 & 31.00 & 103.00 & 37.00 & 331.00 & 1.80 & 4.60 \\
\hline B-7 (Gray bentonite) & 1.90 & 0.05 & 12.70 & 30.00 & 11.90 & 34.00 & 4.70 & 35.00 & 1.00 & 13.00 & 24.00 & 17.00 & 35.00 & 131.00 & 0.25 & 7.00 \\
\hline B-8 (Pink bentonite) & 1.70 & 0.10 & 5.00 & 22.00 & 39.40 & 30.00 & 2.57 & 5.00 & 0.05 & 5.10 & 16.00 & 7.00 & 51.00 & 208.00 & 0.90 & 5.00 \\
\hline C-1 (Grayish White bentonite) & 1.40 & 0.05 & 7.70 & 70.00 & 19.60 & 32.00 & 2.68 & 7.00 & 2.10 & 6.40 & 50.00 & 14.00 & 58.00 & 431.00 & 1.60 & 7.70 \\
\hline S-1 (Silicic Samples) & 1.60 & 0.05 & 6.20 & 304.00 & 4.70 & 26.00 & 3.32 & 2.00 & 16.30 & 7.10 & 337.00 & 16.00 & 122.00 & 291.00 & 0.90 & 1.70 \\
\hline T-1 ( Fresh Volcanic fragments) & 1.90 & 0.40 & 8.10 & 99.00 & 1.80 & 47.00 & 4.12 & 9.00 & 4.60 & 12.80 & 75.00 & 93.00 & 60.00 & 210.00 & 0.90 & 5.90 \\
\hline
\end{tabular}




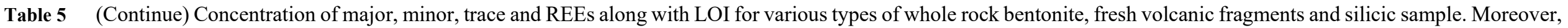
the detection limits for the elements and the values of Eu and Ce anomalies by $(\mathrm{La} / \mathrm{Yb})_{\mathrm{N}},(\mathrm{Gd} / \mathrm{Yb})_{\mathrm{N}}$ and $(\mathrm{La} / \mathrm{Sm})_{\mathrm{N}}$ are listed, nd= not detected.

\begin{tabular}{|c|c|c|c|c|c|c|c|c|c|c|c|c|c|c|c|c|c|}
\hline Element & Sr & Ta & Th & TI & $\mathbf{U}$ & $\mathbf{V}$ & $\mathbf{W}$ & $\mathbf{Y}$ & $\mathbf{Z n}$ & $\mathbf{Z r}$ & Se & Sn & La & Ce & Pr & Nd & Sm \\
\hline Unit & ppm & ppm & ppm & ppm & ppm & ppm & ppm & ppm & ppm & ppm & Ppm & ppm & ppm & ppm & ppm & ppm & ppm \\
\hline Detection limit & 1 & 0.1 & 0.1 & 0.1 & 0.1 & 1 & 1 & 0.5 & 1 & 5 & 0.5 & 0.1 & 1 & 0.5 & 0.05 & 0.5 & 0.02 \\
\hline A-1(Fresh Volcanic fragments) & 406.40 & 0.82 & 13.99 & 0.31 & 3.20 & 99.00 & 2.10 & 18.80 & 93.00 & 177.00 & 1.34 & 2.00 & 29.00 & 65.00 & 5.70 & 22.70 & 5.06 \\
\hline B-1(Green bentonite) & 349.20 & 0.78 & 9.66 & 0.61 & 2.30 & 125.00 & 2.10 & 22.00 & 84.00 & 170.00 & 0.86 & 1.80 & 29.00 & 64.00 & 6.11 & 25.30 & 5.43 \\
\hline B-2 (White bentonite) & 420.60 & 0.51 & 3.72 & 0.14 & 1.80 & 44.00 & 0.50 & 16.50 & 42.00 & 62.00 & 0.79 & 1.40 & 18.00 & 34.00 & 2.18 & 11.60 & 2.83 \\
\hline B-3 (Yellow bentonite) & 367.90 & 0.53 & 3.21 & 0.97 & 2.30 & 44.00 & 1.20 & 15.40 & 298.00 & 52.00 & 0.76 & 1.30 & 15.00 & 32.00 & 1.58 & 10.20 & 2.61 \\
\hline B-4 (Red bentonite) & 331.40 & 0.52 & 3.52 & 0.61 & 1.50 & 45.00 & 0.50 & 16.30 & 183.00 & 57.00 & 0.66 & 1.20 & 16.00 & 34.00 & 1.82 & 10.90 & 2.62 \\
\hline B-5 (Low Pink bentonite) & 161.90 & 0.49 & 3.74 & 0.19 & 0.97 & 48.00 & 0.50 & 13.20 & 58.00 & 52.00 & 2.11 & 1.30 & 15.00 & 30.00 & 1.34 & 9.70 & 2.22 \\
\hline B-6 (Cream bentonite) & 361.60 & 0.56 & 5.42 & 0.51 & 3.40 & 48.00 & 0.50 & 14.60 & 234.00 & 73.00 & 1.12 & 1.10 & 19.00 & 39.00 & 2.34 & 12.10 & 2.65 \\
\hline B-7 (Gray bentonite) & 659.60 & 0.82 & 14.04 & 0.32 & 3.10 & 75.00 & 1.40 & 6.70 & 78.00 & 160.00 & 0.91 & 1.10 & 33.00 & 66.00 & 5.92 & 23.30 & 3.70 \\
\hline B-8 (Pink bentonite) & 470.00 & 0.47 & 2.70 & 0.18 & 1.10 & 37.00 & 0.50 & 14.80 & 32.00 & 50.00 & 1.01 & 1.00 & 14.00 & 28.00 & 1.26 & 9.30 & 2.26 \\
\hline C-1 (Grayish White bentonite) & 253.00 & 0.49 & 3.59 & 0.36 & 1.00 & 62.00 & 0.50 & 14.60 & 38.00 & 66.00 & 1.08 & 1.10 & 16.00 & 33.00 & 1.90 & 11.30 & 2.72 \\
\hline S-1 (Silicic Samples) & 2321.00 & 0.61 & 5.12 & 0.24 & 1.64 & 15.00 & 1.20 & 20.10 & 16.00 & 95.00 & 1.62 & 1.50 & 26.00 & 46.00 & 3.94 & 16.90 & 3.74 \\
\hline T-1 (Fresh Volcanic fragments) & 532.90 & 0.74 & 12.03 & 0.49 & 4.50 & 67.00 & 1.80 & 6.40 & 163.00 & 143.00 & 0.87 & 1.30 & 31.00 & 64.00 & 5.16 & 19.90 & 3.34 \\
\hline Element & 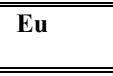 & $\overline{\text { Gd }}$ & Tb & $\overline{\text { Dy }}$ & "Ho & 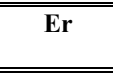 & 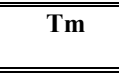 & Yb & Lu & La/Sm & 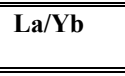 & 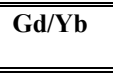 & $\begin{array}{r}\mathbf{E u} / \mathbf{E} \\
\mathbf{u}^{*} \\
\end{array}$ & $\overline{\mathrm{Ce} / \mathrm{Ce}}$ & 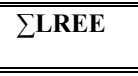 & 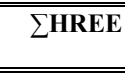 & 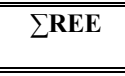 \\
\hline Unit & ppm & ppm & ppm & ppm & ppm & ppm & ppm & ppm & ppm & Ppm & Ppm & ppm & ppm & ppm & ppm & ppm & ppm \\
\hline Detection limit & 0.1 & 0.05 & 0.1 & 0.05 & 0.05 & 0.05 & $\mathbf{0 .}$ & 0.05 & 0.1 & - & - & - & - & - & - & - & - \\
\hline A-1(Fresh Volcanic fragments) & 1.47 & 4.67 & 0.73 & 4.45 & 0.71 & 2.70 & 0.39 & 2.00 & 0.35 & 3.56 & 9.80 & 1.88 & 0.90 & 1.08 & 128.93 & 16.00 & 144.93 \\
\hline B-1(Green bentonite) & 1.34 & 5.28 & 0.80 & 5.3 & 0.84 & 3.15 & 0.47 & 2.50 & 0.42 & 3.32 & 7.84 & 1.70 & 0.74 & 1.04 & 131.18 & 18.76 & 149.94 \\
\hline B-2 (White bentonite) & 0.41 & 2.86 & 0.53 & 3.6 & 0.62 & 2.61 & 0.40 & 2.00 & 0.41 & 3.95 & 6.08 & 1.15 & 0.43 & 0.94 & 69.02 & 13.03 & 82.05 \\
\hline B-3 (Yellow bentonite) & 0.36 & 2.64 & 0.51 & 3.47 & 0.59 & 2.48 & 0.38 & 1.90 & 0.4 & 3.57 & 5.33 & 1.12 & 0.41 & 1.05 & 61.75 & 12.37 & 74.12 \\
\hline B-4 (Red bentonite) & 0.46 & 2.78 & 0.53 & 3.54 & 0.59 & 2.39 & 0.37 & 2.00 & 0.38 & 3.80 & 5.41 & 1.12 & 0.51 & 1.04 & 65.34 & 12.58 & 78.38 \\
\hline B-5 (Low Pink bentonite) & 0.42 & 2.18 & 0.45 & 2.93 & 0.50 & 2.05 & 0.34 & 1.60 & 0.31 & 4.20 & 6.33 & 1.10 & 0.57 & 0.99 & 58.68 & 10.36 & 69.04 \\
\hline B-6 (Cream bentonite) & 0.53 & 2.46 & 0.46 & 3.17 & 0.53 & 2.11 & 0.35 & 1.80 & 0.35 & 4.46 & 7.13 & 1.10 & 0.62 & 1.02 & 75.62 & 11.23 & 86.85 \\
\hline B-7 (Gray bentonite) & 1.12 & 2.79 & 0.38 & 2.00 & 0.30 & 0.97 & 0.15 & 0.80 & 0.11 & 5.54 & 27.78 & 2.81 & 1.03 & 0.98 & 133.04 & 7.50 & 140.54 \\
\hline B-8 (Pink bentonite) & 0.32 & 2.31 & 0.49 & 3.17 & 0.54 & 2.25 & 0.37 & 1.80 & 0.35 & 3.85 & 5.26 & 1.03 & 0.42 & 0.99 & 55.14 & 11.28 & 66.42 \\
\hline C-1 (Grayish White bentonite) & 0.81 & 2.63 & 0.47 & 3.21 & 0.53 & 2.12 & 0.33 & 1.70 & 0.30 & 3.66 & 6.36 & 1.25 & 0.90 & 1.01 & 65.73 & 11.29 & 77.02 \\
\hline S-1 (Silicic Samples) & 0.86 & 3.93 & 0.62 & 4.07 & 0.65 & 2.44 & 0.39 & 1.80 & 0.34 & 4.32 & 9.76 & 1.76 & 0.67 & 0.87 & 97.44 & 14.24 & 111.68 \\
\hline T-1 (Fresh Volcanic fragments) & 0.96 & 2.33 & 0.34 & 1.85 & 0.28 & 0.95 & 0.16 & 0.80 & 0.10 & 5.77 & 26.18 & 2.35 & 1.02 & 1.02 & 124.36 & 6.81 & 131.17 \\
\hline
\end{tabular}




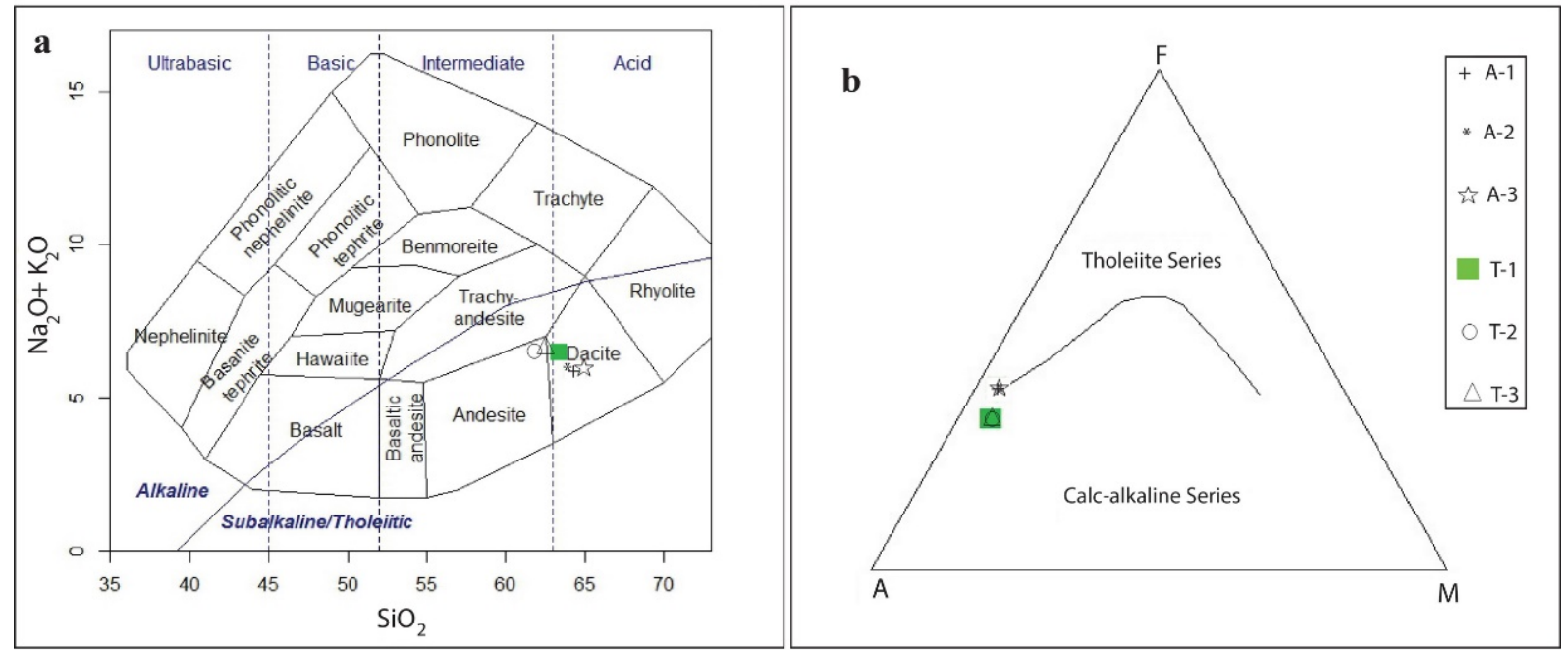

Fig. 19 a) Position of Mollaahmad Pass data points on a) bivariate $\mathrm{Na}_{2} \mathrm{O}+\mathrm{K}_{2} \mathrm{O}-\left(\mathrm{SiO}_{2}\right)$ chart $(\mathrm{Cox}$ et al., 1979) b) ternary AFM plot (Irvin and Baraga, 1971).

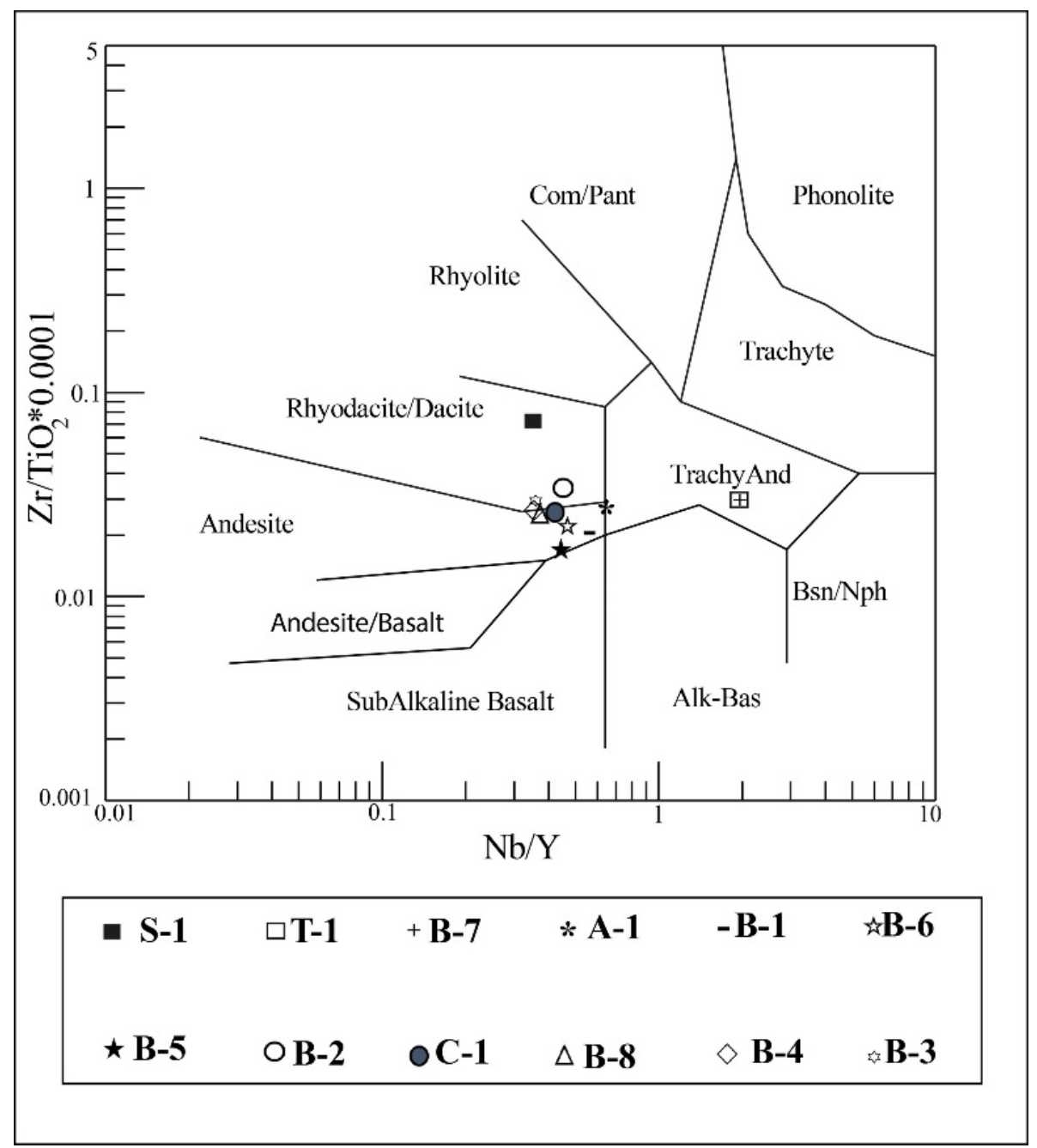

Fig. 20 Position of Mollaahmad Pass data points on $\mathrm{Nb} / \mathrm{Y}$ versus $\mathrm{Zr} / \mathrm{TiO}_{2}$ bivariate plot (Winchester and Floyd, 1977). 


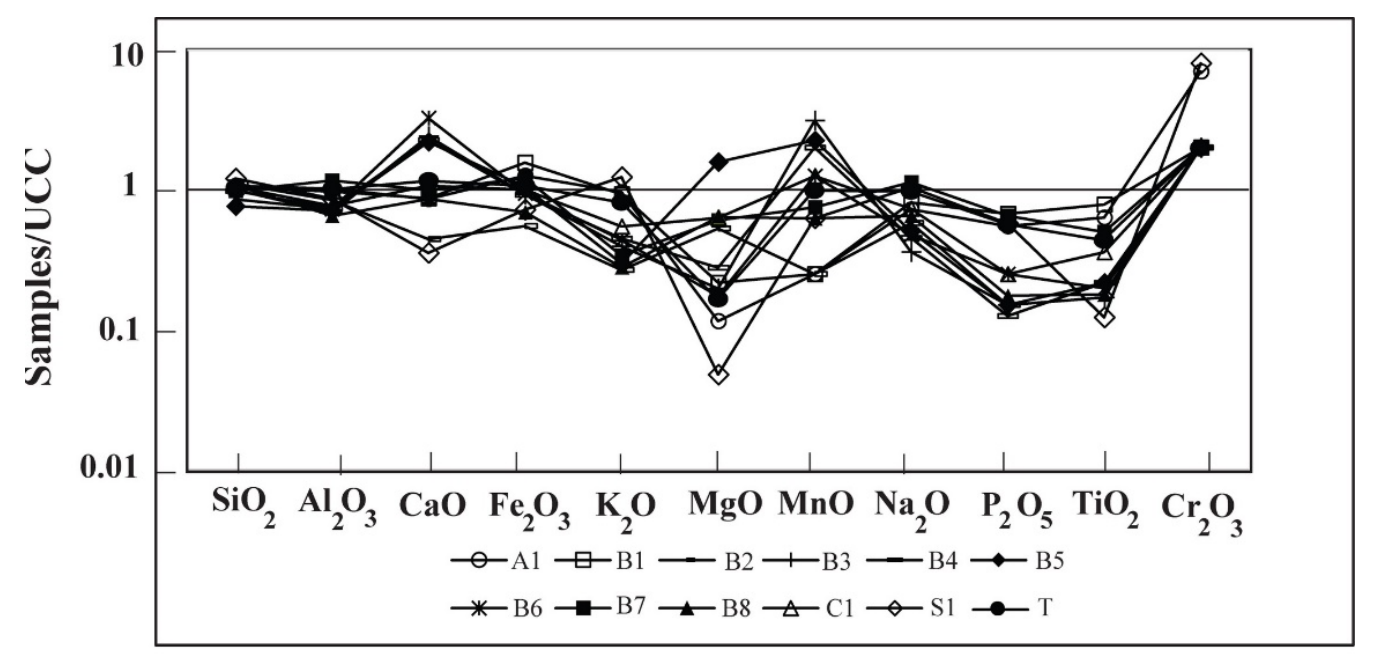

Fig. 21 Diagram of normalized major and minor oxides in upper continental crust (UCC) (Taylor, 1964).

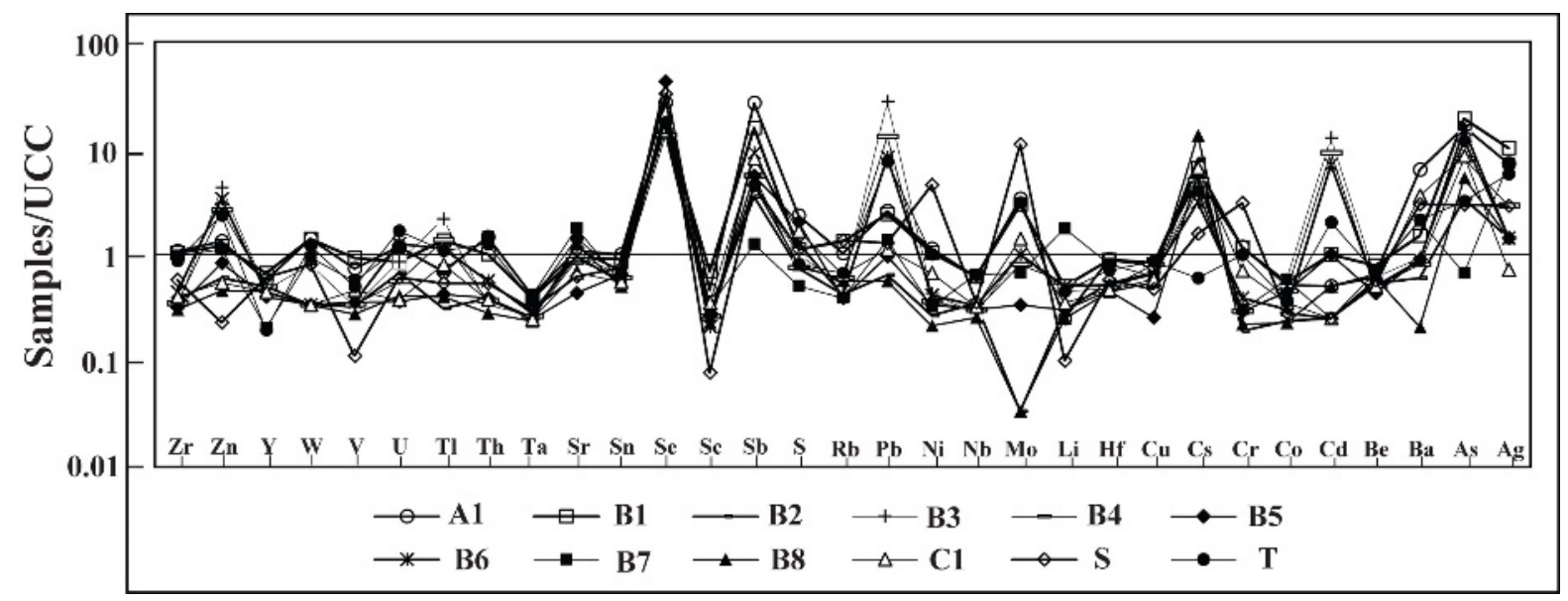

Fig. 22 Diagram of normalized trace elements to chondrite (Taylor and MacLennan, 1985).

montmorillonite or formation of calcite and dolomite minerals (Vogt and Kostner, 1978; Christidis, 1998). Increasing in $\mathrm{SiO}_{2}$ due to formation of chalcedony and entry of silica during destruction of plagioclase. Leaching of $\mathrm{SiO}_{2}$ and $\mathrm{Na}_{2} \mathrm{O}$ during bentonitization can be attributed to the alteration of shard glass and plagioclase (Zeilinski, 1982).

Enrichment of $\mathrm{Fe}_{2} \mathrm{O}_{3}$ is possibly related to the formation of Fe-oxides/ hydroxides or fixation and incorporation of this component in the crystal lattice of montmorillonite (Laviano and Mangelli, 1996). $\mathrm{Fe}^{3+}$ oxide minerals may postdate the smectite and might have formed from oxidation of precursor Febearing phase possibly pyrite or biotite (Arslan et al., 2010). Depletion of $\mathrm{Ni}, \mathrm{Co}, \mathrm{Fe}, \mathrm{Mg}$, Ti, Mo and $\mathrm{Zn}$ attributed to ferromagnesian minerals. $\mathrm{Ca}$ and $\mathrm{Mg}$ can be attributed to the formation of $\mathrm{Ca}$ - smectite and rare calcite (Arslan et al., 2010). The Mg content can increase by up to 15 times during the conversion of rhyolite to bentonite (Zeilinski, 1982). Enrichment in $\mathrm{Mg}$ content indicate a circulation between sea water and the precursor material of bentonites during and/or after the alteration period (Fisher and Schmincke,
1984). The enrichment of $\mathrm{Mg}$ in smectite could be attributed not only to seawater but also to the circulation of ground water (Arslan et al., 2010). Depletion of $\mathrm{Al}$ and $\mathrm{P}$ elements can be related to immigration during bentonitization processes in the system. Enrichment of $\mathrm{Mn}$ in some samples likely owns to presence of this element in interlayer sites of montmorillonite or its substitution for $\mathrm{Ca}^{2+}$ (Munchngos, 2006). In Mollaahmad Pass bentonite deposit, alteration began with hydration of the pumice debris and volcanic glass, which did not dissolve the glass but probably involved a cation exchange between the fluid phase and the parent rock (White and Claasen, 1980). Thus, the relatively high LOI of B5 sample might either be due to an inherent high water content of the parent rock or might be considered as the first indication for alteration, since hydration of acidic volcanic glass might not lead to formation of secondary minerals (Shiraki and Iijama, 1990). Cu, $\mathrm{Zn}, \mathrm{As}, \mathrm{Ag}, \mathrm{Li}, \mathrm{Mo}, \mathrm{U}, \mathrm{Sb}$, and Ta enrich in the system by surface adsorption of clay minerals or Fe-oxides (Fatahi et al., 2016). According to the investigation, alteration of feldspars and surface adsorption are the 

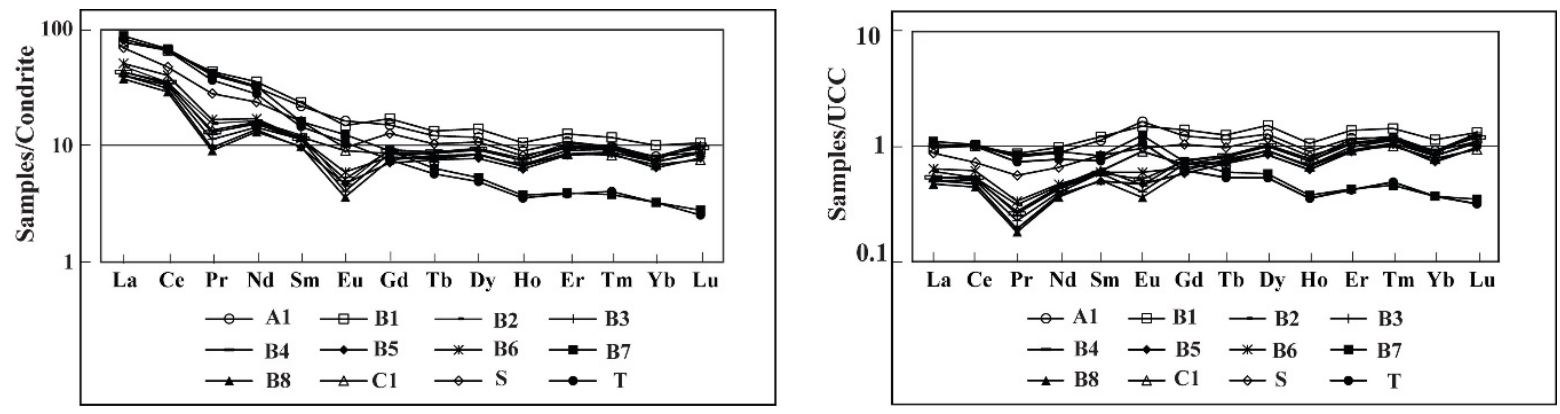

Fig. 23 Diagram of normalized REE to a) UCC (Taylor, 1964) and b) chondrite (Taylor and MacLennan, 1985).

major factors of dual behavior of $\mathrm{Pb}$ during bentonitization (Fung and Shaw, 1978). The positive correlation between $\mathrm{K}$ and $\mathrm{Rb}(\mathrm{r}=0.95)$ (Table 6) may be related to replacing of $\mathrm{K}$ by $\mathrm{Rb}$ in the kaolinite, illite and feldspars minerals (Plank and Langmuir, 1998). Loss of the $\mathrm{Rb}$ may be related to breakdown of biotite (Abdioglu and Arslan, 2005). Also, enrichment of Sr and $\mathrm{Ba}$ can be owned to substitution of $\mathrm{Ca}$ by $\mathrm{Ba}$ and $\mathrm{Sr}$ in calcite or surface adsorption by clay minerals (Costa and Araujo, 1996). $\mathrm{SiO}_{2}$, secondary iron oxides, Mn phases and their subsequently fixation in the system (Zeilinski, 1982) can adsorb partially the dissolved uranium in the oxidizing conditions. REEs are mobile under acidic and are fixated under alkaline conditions. In this regard, high $\mathrm{pH}$ fluids responsible for bentonitization is the major factor for REEs enrichments. It seems that six factors control the mobilization, differentiation and distribution of elements in studied bentonites:

1 Discrepancy in rate of alteration intensity in source materials: with increasing of $\mathrm{pH}$ and $\mathrm{SiO}_{2}$ activity in system, without silicate minerals such as gibbsite, bohmite and diaspore, low silicate minerals such as kaolinite and finally smectite group minerals are precipitated from fluids responsible for alteration, respectively (Garrels, 1984).

2 Incorporation in crystal lattice: $\mathrm{Fe}, \mathrm{Mg}$ and $\mathrm{Ti}$ are generally fixed during bentonite formation by structural incorporation in clays or in secondary oxides and hyroxides (Zeilinski, 1982). Fixation of $\mathrm{Zn}$ could be attributed to structural incorporation in clay minerals (Vogt and Kostner, 1978). Complex-forming ligands: The ligands forming complexes with $\mathrm{REE}$ in low $\mathrm{pH}$ are mainly sulfates, chlorides and fluorides, and in alkaline conditions is carbonate that are able remove them from the system (Pandarinath et al., 2008).

3 Surface adsorption: (clay minerals have negative charge in their surface and are able to absorb many cations).

4 Difference in stability of primary minerals: (unstable minerals such as plagioclase, pumice debris and shard glass easily converted to smectite group minerals by action of alteration solution (Fatahi et al, 2015). Despite the stable minerals partially altered or remain as residual minerals in dense fraction of weathering products, some of these heavy minerals are hosts for different elements, for example anatase, sphene, rutile, tourmaline and garnet hosts for $\mathrm{Nb}-\mathrm{Ti}$ (Brimhall and Dietrich, 1986), allanite host for REE and Ti (Jiang et al., 2003) and magmatic melanite garnet and titanite are two major hosts for Ti (Jiang et al., 2003).

5 Permeability and porosity: Circulation and infiltration of pore waters and mobilization of elements controlled by permeability and porosity of the volcanic rocks during formation of bentonites, which controls the chemical leaching processes (Ozdamar et al., 2014). In mollaahmad Pass bentonite deposit, fluids pass through the primary porosity of conglomerate, sandstone, tuffs and volcanic cavities. It directly effects on Water/Rock ratio and progression of alteration (Fatahi et al., 2015). The different alteration zones are a function of the $\mathrm{W} / \mathrm{R}$ ratio, which in turn controls the degree of leaching of elements (Christidis, 1998).

\subsubsection{REE PATTERNS AND EU AND CE ANOMALIES}

The chondrite normalized REE distribution patterns of parent rock (fresh volcanic fragments), bentonite and silicic sample are almost parallel (Fig. 23). In this study, the $\mathrm{Eu}$ and $\mathrm{Ce}$ anomalies calculated in the following equations (Table 5):

$\mathrm{Eu} / \mathrm{Eu}^{*}=\left(\mathrm{Eu}_{\mathrm{N}}\right) / \sqrt{ } \mathrm{Sm}_{\mathrm{N}} \times \mathrm{Gd}_{\mathrm{N}}$

(Taylor and McLennan, 1985)

$\mathrm{Ce} / \mathrm{Ce}^{*}=\left(3 \mathrm{Ce}_{\mathrm{N}}\right) /\left(2 \mathrm{La}_{\mathrm{N}}+\mathrm{Nd}_{\mathrm{N}}\right)$

(Taylor and McLennan, 1985)

In the equations, $\mathrm{N}$ denotes normalization of the REE to chondrite (Taylor and Maclenann, 1985). Eu anomaly varies from 0.90 to 1.02 in parent rock (fresh volcanic fragments), within the range of 0.42 to 1.03 in bentonites and about 0.67 in the silicic sample. Similarly, the $\mathrm{Ce}$ anomaly in fresh volcanic rock ranging between 1.02 and 1.08 in bentonites varies from 0.98 to 1.05 and about 0.87 in silicic samples. 


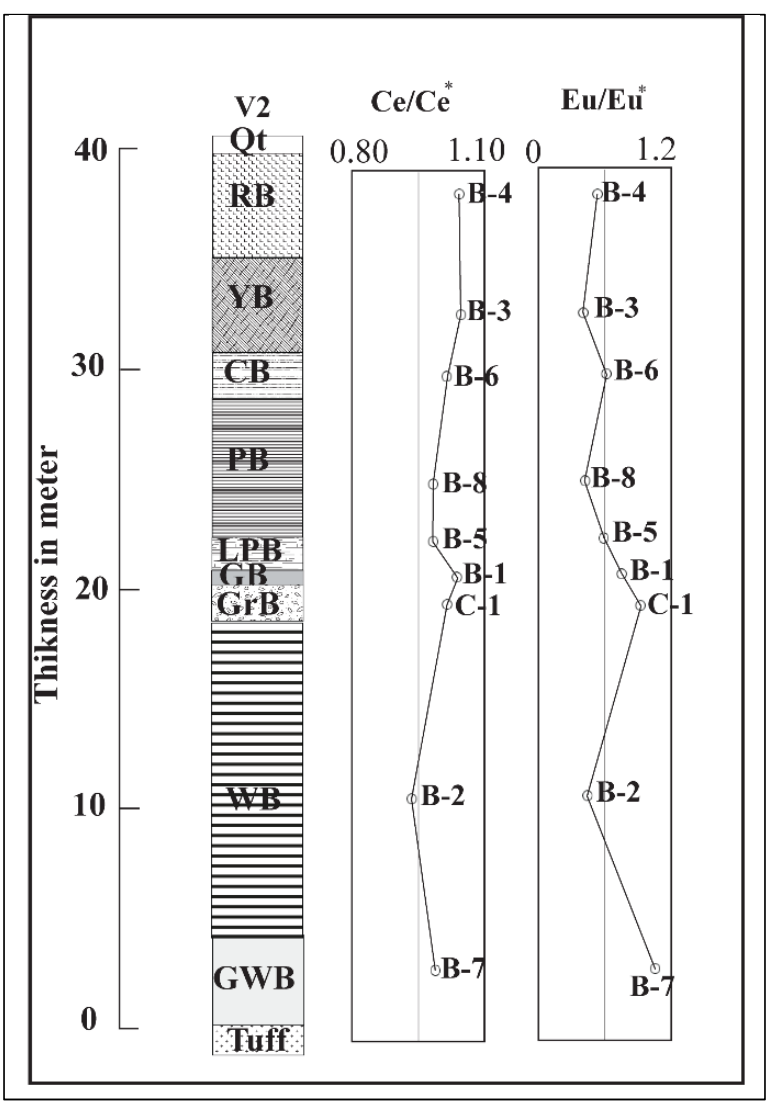

Fig. 24 Variation of $\mathrm{Eu} / \mathrm{Eu}^{*}$ and $\mathrm{Ce} / \mathrm{Ce}^{*}$ anomalies from V2 profile of Mollaahmad Pass bentonite layers into depth.

The ionic radius of $\mathrm{Eu}^{2+}$ is about $1.25 \mathrm{~A}^{\circ}$ and is near to that of $\mathrm{Ca}^{2+}\left(1 \mathrm{~A}^{\circ}\right)$ and $\mathrm{Sr}^{2+}\left(1.13 \mathrm{~A}^{\circ}\right)$, so Eu can substitute for $\mathrm{Ca}$ and $\mathrm{Sr}$ in plagioclase crystal structure (Laufer et al., 1984). It seems that during the destruction of plagioclase, $\mathrm{Ca}$ and $\mathrm{Sr}$ are released and transported by solution and lead to negative $\mathrm{Eu}$ anomaly in the primary step of bentonitization process. Positive $\mathrm{Eu}$ anomaly may be related to precipitation of $\mathrm{Ca}$ and $\mathrm{Sr}$ minerals during alteration system.

The positive Ce anomaly during bentonitization is due to conversion of $\mathrm{Ce}^{3+}$ to insoluble $\mathrm{Ce}^{4+}$ in oxidizing conditions.

The amount of $\mathrm{Ce} / \mathrm{Ce}^{*}$ anomalies in red and yellow bentonite is 1.04 and 1.05 , respectively. Moreover, for interlayers of white bentonite with bitumen is 0.94 . This is due to formation of red and yellow bentonite in oxidizing conditions (due to surface leveling and most mixing with river fresh water) and formation of white bentonite in reduction conditions (due to depth and coexisting with organo materials) (Fig. 24). Before starting the geochemical investigation, for making sure that silicic samples are not chert-type or other types that transported by rivers into sedimentary basin. Detailed mineralogical studies have done and then, chalcedony separated from fill volcanic cavities.
The behavior of Eu in silicic samples depends on decomposition of plagioclase in host rock (Goetz et al., 1998). Therefore, Eu in S-1 sample exhibits a negative anomaly (Fig. 24). The normalized distribution pattern of REE in silicic sample is similar to bentonitized sample and parent rock. It indicates that this type of silica may be related to destruction of plagioclase or shard glass in parent rock.

Generally, it seem that physico-chemical conditions of fluids responsible for alteration is varying and cause to swing in $\mathrm{Eh}$ and $\mathrm{pH}$. This subject effects on the behavior of Eu anomaly. This may be related to mixing of brine water in the lacustrine environment with fresh river water, lake water rotation or sedimentary basin floor or lake level fluctuations while formation of Mollaahmad Pass bentonite deposits (Scott et al., 2012).

In normalized bentonite sample to parent rock, the $(\mathrm{La} / \mathrm{Yb})_{\mathrm{N}}$ ratio varying from 5.26 to 27.78 (Table 5). However, the range of $(\mathrm{La} / \mathrm{Sm})_{\mathrm{N}}$ ratio is 3.32 to 5.77 and $(\mathrm{Gd} / \mathrm{Yb})_{\mathrm{N}}$ varying from 1.03 to 2.81 (Table 5). High differentiation of LREEs from HREEs occurs (especially, in B-7 sample with about 27.78) (Fig. 25). The REE behavior during alteration of parent rock to bentonite related to protolith properties and physico-chemical conditions (Munchangous, 2006).

In addition, concentration of REEs is directly and/ or indirectly controlled by $\mathrm{pH}$ variation of the environment (Goldstein and Jacobseny, 1988). Light REE (LREEs) are mobile under acidic and heavy REE (HREEs) are mobile under alkaline conditions (Pandarinath et al., 2008). Therefore, high $\mathrm{pH}$ fluids cause to mobilization of HREEs and consequently increasing of the $(\mathrm{La} / \mathrm{Yb})_{\mathrm{N}}$ ratio.

The ligands forming complexes with REE in low $\mathrm{pH}$ are principally sulfates, chlorides and fluorides, contrary to alkaline conditions, carbonate ligands can form complexes with REE and remove them from the system (Pandarinath et al., 2008). Competition among $\mathrm{CO}_{3}{ }^{2-}$ ligands for forming complexes with HREE is believed to be the most important controlling factor for mobilization of HREE from alteration system.

\subsubsection{MOBILIZATION, DISTRIBUTION AND DIFFERENTIATION OF REES}

For describing how mobilization and differentiation of REEs play role in the Mollaahmad Pass bentonite deposit, calculation of correlation between $(\mathrm{La} / \mathrm{Sm})_{\mathrm{N}},(\mathrm{La} / \mathrm{Yb})_{\mathrm{N}}$ and $(\mathrm{Gd} / \mathrm{Yb})_{\mathrm{N}}$ with some major, minor and trace elements is necessary (Rollinsone, 1993) (Table 6). The positive correlation between $(\mathrm{La} / \mathrm{Sm})_{\mathrm{N}}$ with $\mathrm{Al}, \mathrm{Na}, \mathrm{P}, \mathrm{Hf}, \mathrm{Nb}$, Th and $\mathrm{Zr}$ $(r=0.27$ to 0.61$)$ indicate the role of aluminum-content minerals (smectite and zeolite), albite, different type of phosphate minerals and specially zircon for differentiation of LREE from MREE in system. The very high correlation between $\mathrm{Hf}$ and $\mathrm{Nb}$ with $\mathrm{Zr}$ ( $\mathrm{r}>$ 0.98) may show the substitution of them into zircon. 


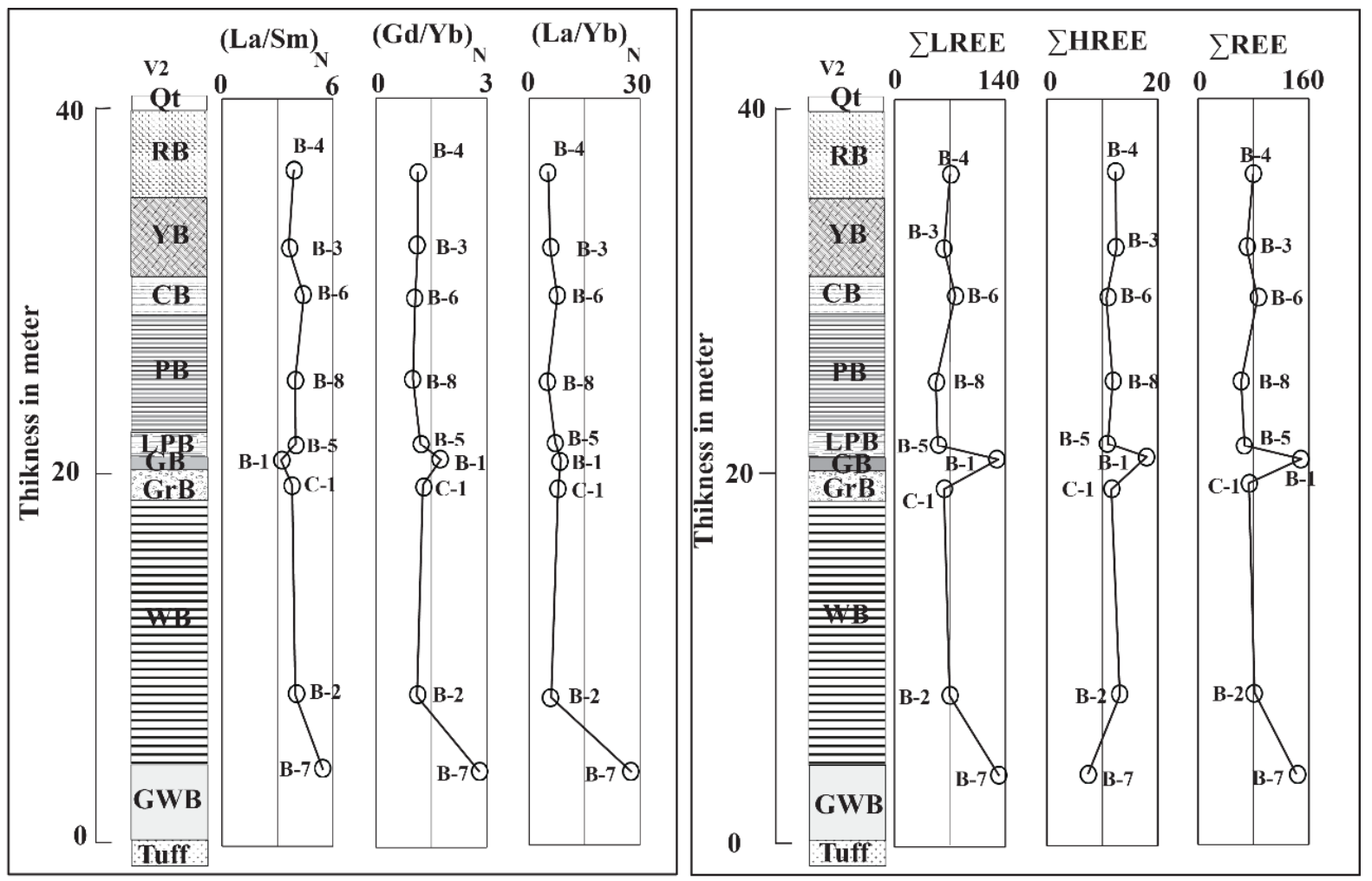

Fig. 25 Variation of $(\mathrm{La} / \mathrm{Yb})_{\mathrm{N}},(\mathrm{Gd} / \mathrm{Yb})_{\mathrm{N}}$ and $(\mathrm{La} / \mathrm{Sm})_{\mathrm{N}}, \Sigma \mathrm{LREE}, \Sigma \mathrm{HREE}$ and $\Sigma \mathrm{REE}$ from V2 profile of Mollaahmad Pass bentonite layers into depth.

The positive correlation between $(\mathrm{La} / \mathrm{Yb})_{\mathrm{N}}$ with $\mathrm{Al}, \mathrm{Fe}, \mathrm{Na}, \mathrm{P}, \mathrm{Ti}, \mathrm{Co}, \mathrm{Hf}, \mathrm{Nb}, \mathrm{Ze}$, Th and $\mathrm{V}$ ( $\mathrm{r}=0.25$ to $0.88)$ and $(\mathrm{Gd} / \mathrm{Yb})_{\mathrm{N}}(\mathrm{r}=0.37$ to 0.94$)$ indicate that $\mathrm{Al}-$ bearing minerals, Fe-bearing minerals (for example hematite, goethite or the resistant primary minerals such as pyroxene, amphibole and biotite), albite, different types of phosphate minerals, zircon and minerals containing $\mathrm{Ti}, \mathrm{Co}, \mathrm{U}$ and $\mathrm{Th}$ have major role for differentiation of LREE and MREE from HREE (Table 6). It seems that difference in stability of primary minerals containing REE are the major factors that effect on the irregular patterns of REE in different parts of the alteration profile.

\subsubsection{THE REE HOSTED MINERALS}

Several groups of minerals are introduced as REE hosted minerals in alteration product, can be cited to clay minerals, secondary phosphate minerals (Aja, 1998) with Fe-oxides/hydroxides and Mn minerals as major groups (Lopez et al., 2005).

The XRD analyses can be detected minerals with abundance above $4 \%$ and SEM-EDS limited done on several samples. For this reason, may be other mineral phases exiting in bentonite samples that not detected by two mentioned methods. In this purpose, correlation coefficients (Rollinson, 1993) between REE with some major and minor oxides and trace elements calculated. Positive correlation between LREE with Fe, P, Ti, Cr, Hf, Ni, V, Y, Zr and $\mathrm{Cr}$ (r= 0.27 to 0.95 ) has observed that its amount is maximum for $\mathrm{Y}$ (Table 6). Also, Positive correlation exists between HREE and $\mathrm{Si}, \mathrm{Al}, \mathrm{Fe}, \mathrm{Na}, \mathrm{P}, \mathrm{Ti}, \mathrm{Co}, \mathrm{Cr}, \mathrm{Hf}$, $\mathrm{Nb}, \mathrm{Ni}$ and $\mathrm{Zr}(\mathrm{r}=0.21$ to 0.99$)$ that this value is maximum for $\mathrm{Zr}$, $\mathrm{Nb}$ and $\mathrm{Hf}$ (Table 6).

In this regard, smectite, albite, secondary phosphate and Iron oxides/hydroxides, minerals containing $\mathrm{Cr}, \mathrm{Co}$, $\mathrm{Ti}$ and zircon (with substitution $\mathrm{Nb}$ and $\mathrm{Hf}$ ) are host for HREE that zircon has the major role. Secondary Fe oxides/ hydroxides and phosphate minerals, the minerals content $\mathrm{Ni}$ and $\mathrm{Cr}$, zircon and specially minerals content $\mathrm{Y}$ are principle hosted REE minerals. The positive correlation between $\mathrm{Ni}$ and $\mathrm{Cr}$ with REE and $\mathrm{Si}$ and $\mathrm{Al}$ can be related to surface adsorption of clay, but cannot ignore the role of primary resistant ferromagnesian minerals.

\subsection{GENESIS}

According to field observations, three following steps can be recognized during formation of Mollaahmad Pass bentonit deposits (Fig. 26):

1 Transportation of volcanic boulders and the volcanic fragments containing sandstone and conglomerate, tuff and broken wood fragments by rivers and precipitation in margin of the OligoMiocene lacustrine environment.

2 Bentonitization: including reaction between reactivity segments such as plagioclase, shard glass and pumice debris with transgressive brine water. In study area, lake-level fluctuations are conducive to complex cross-cutting relationships 


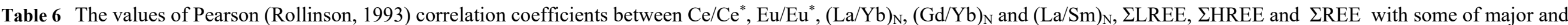
minor oxides and trace elements.

\begin{tabular}{|c|c|c|c|c|c|c|c|c|c|c|c|c|c|c|c|c|c|c|c|c|c|c|c|c|c|c|c|c|c|}
\hline & $\begin{array}{l}\mathrm{Si} \\
\end{array}$ & AI & $\begin{array}{l}\mathrm{Ca} \\
\end{array}$ & $\mathrm{Fe}$ & $\overline{~ K K}$ & Mn & Na & $\bar{P}$ & Ti & Ba & $\begin{array}{l}\text { Co } \\
\end{array}$ & $\overline{C r}$ & Hf & Nb & $\mathrm{Ni}$ & Rb & Sr & $\begin{array}{l}\text { Th } \\
\end{array}$ & $\bar{U}$ & $\bar{v}$ & $\overline{Y Y}$ & $\mathrm{Zr}$ & $\overline{E u / E u^{*}}$ & $\bar{c} \mathrm{Ce} / \mathrm{Ce}^{*}$ & $\begin{array}{l}\text { ¿LREE } \\
\end{array}$ & 'HREE & $(\mathbf{L a} / \mathbf{S m})_{\mathrm{N}}$ & $(\mathbf{L a} / \mathbf{Y b})_{\mathbf{N}}$ & 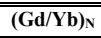 \\
\hline $\mathbf{S i}$ & 1.00 & & & & & & & & & & & & & & & & & & & & & & & & & & & & \\
\hline Al & 0.22 & 1.00 & & & & & & & & & & & & & & & & & & & & & & & & & & & \\
\hline $\mathrm{Ca}$ & -0.79 & -0.46 & 1.00 & & & & & & & & & & & & & & & & & & & & & & & & & & \\
\hline $\mathrm{Fe}$ & -0.34 & 0.49 & 0.13 & 1.00 & & & & & & & & & & & & & & & & & & & & & & & & & \\
\hline $\mathrm{K}$ & 0.53 & 0.26 & -0.37 & 0.23 & 1.00 & & & & & & & & & & & & & & & & & & & & & & & & \\
\hline Mn & -0.53 & -0.52 & 0.72 & -0.01 & -0.32 & 1.00 & & & & & & & & & & & & & & & & & & & & & & & \\
\hline $\mathrm{Na}$ & 0.48 & 0.80 & -0.69 & 0.25 & 0.51 & -0.63 & 1.00 & & & & & & & & & & & & & & & & & & & & & & \\
\hline $\mathbf{P}$ & 0.33 & 0.84 & -0.47 & 0.59 & 0.66 & -0.54 & 0.86 & 1.00 & & & & & & & & & & & & & & & & & & & & & \\
\hline $\mathrm{Ti}$ & 0.00 & 0.67 & -0.27 & 0.87 & 0.23 & -0.42 & 0.43 & 0.68 & 1.00 & & & & & & & & & & & & & & & & & & & & \\
\hline Ba & 0.36 & 0.39 & -0.38 & 0.21 & 0.59 & -0.17 & 0.63 & 0.51 & 0.23 & 1.00 & & & & & & & & & & & & & & & & & & & \\
\hline Co & -0.33 & 0.43 & 0.26 & 0.76 & -0.01 & 0.43 & 0.06 & 0.35 & 0.55 & 0.07 & 1.00 & & & & & & & & & & & & & & & & & & \\
\hline $\mathrm{Cr}$ & 0.57 & 0.20 & -0.44 & -0.02 & 0.94 & -0.31 & 0.56 & 0.58 & -0.01 & 0.60 & -0.18 & 1.00 & & & & & & & & & & & & & & & & & \\
\hline $\mathrm{Cu}$ & 0.30 & 0.23 & 0.04 & 0.24 & 0.07 & -0.18 & -0.10 & 0.14 & 0.41 & -0.13 & 0.25 & -0.17 & & & & & & & & & & & & & & & & & \\
\hline Hf & 0.16 & 0.88 & -0.35 & 0.73 & 0.39 & -0.52 & 0.65 & 0.89 & 0.86 & 0.22 & 0.53 & 0.22 & 1.00 & & & & & & & & & & & & & & & & \\
\hline $\mathrm{Nb}$ & 0.07 & 0.94 & -0.33 & 0.74 & 0.27 & -0.48 & 0.69 & 0.87 & 0.86 & 0.27 & 0.55 & 0.13 & 0.98 & 1.00 & & & & & & & & & & & & & & & \\
\hline $\mathrm{Ni}$ & 0.58 & 0.16 & -0.42 & -0.15 & 0.89 & -0.25 & 0.53 & 0.50 & -0.15 & 0.56 & -0.22 & 0.99 & 0.13 & 0.04 & 1.00 & & & & & & & & & & & & & & \\
\hline $\mathbf{R b}$ & 0.58 & 0.24 & -0.48 & 0.29 & 0.95 & -0.40 & 0.47 & 0.64 & 0.36 & 0.44 & 0.01 & 0.85 & 0.45 & 0.31 & 0.77 & 1.00 & & & & & & & & & & & & & \\
\hline $\mathrm{Sr}$ & 0.17 & 0.56 & -0.19 & 0.07 & -0.38 & -0.33 & 0.35 & 0.29 & 0.28 & -0.22 & 0.20 & -0.38 & 0.45 & 0.51 & -0.37 & -0.32 & 1.00 & & & & & & & & & & & & \\
\hline Th & -0.01 & 0.94 & -0.22 & 0.66 & 0.17 & -0.39 & 0.71 & 0.84 & 0.72 & 0.27 & 0.55 & 0.08 & 0.91 & 0.96 & 0.02 & 0.15 & 0.61 & 1.00 & & & & & & & & & & & \\
\hline U & -0.17 & 0.49 & 0.33 & 0.33 & 0.01 & -0.10 & 0.16 & 0.42 & 0.28 & -0.09 & 0.35 & -0.08 & 0.54 & 0.53 & -0.09 & -0.10 & 0.55 & 0.63 & 1.00 & & & & & & & & & & \\
\hline $\mathrm{v}$ & -0.15 & 0.53 & -0.09 & 0.89 & 0.10 & -0.29 & 0.21 & 0.52 & 0.97 & 0.08 & 0.58 & -0.18 & 0.77 & 0.76 & -0.32 & 0.24 & 0.23 & 0.62 & 0.30 & 1.00 & & & & & & & & & \\
\hline $\mathbf{Y}$ & 0.44 & -0.24 & -0.22 & 0.01 & 0.68 & -0.23 & -0.13 & 0.11 & 0.10 & 0.03 & -0.23 & 0.56 & 0.06 & -0.13 & 0.50 & 0.78 & -0.55 & -0.34 & -0.24 & 0.10 & 1.00 & & & & & & & & \\
\hline $\mathrm{Zr}$ & 0.17 & 0.90 & -0.36 & 0.74 & 0.44 & -0.53 & 0.74 & 0.94 & 0.85 & 0.34 & 0.50 & 0.29 & 0.99 & 0.98 & 0.19 & 0.47 & 0.43 & 0.93 & 0.52 & 0.74 & 0.01 & 1.00 & & & & & & & \\
\hline $\mathbf{E u} / \mathbf{E u}^{*}$ & 0.00 & 0.74 & -0.24 & 0.58 & 0.26 & -0.30 & 0.75 & 0.70 & 0.60 & 0.75 & 0.36 & 0.21 & 0.60 & 0.71 & 0.14 & 0.16 & 0.24 & 0.76 & 0.29 & 0.48 & -0.37 & 0.70 & 1.00 & & & & & & \\
\hline $\mathrm{Ce} / \mathrm{Ce}^{*}$ & -0.53 & -0.23 & 0.64 & 0.54 & -0.37 & 0.50 & -0.57 & -0.27 & 0.34 & -0.32 & 0.56 & -0.62 & 0.02 & 0.02 & -0.69 & -0.27 & 0.05 & -0.01 & 0.17 & 0.51 & -0.07 & -0.03 & -0.07 & 1.00 & & & & & \\
\hline$\sum$ LREE & 0.39 & -0.02 & -0.25 & 0.27 & 0.65 & -0.31 & -0.04 & 0.28 & 0.39 & 0.01 & 0.00 & 0.46 & 0.33 & 0.15 & 0.37 & 0.79 & -0.37 & -0.09 & -0.09 & 0.39 & 0.95 & 0.27 & -0.23 & 0.07 & 1.00 & & & & \\
\hline$\sum$ HREE & 0.21 & 0.92 & -0.37 & 0.67 & 0.49 & -0.52 & 0.77 & 0.96 & 0.77 & 0.37 & 0.47 & 0.37 & 0.97 & 0.96 & 0.29 & 0.49 & 0.43 & 0.93 & 0.56 & 0.64 & 0.01 & 0.99 & 0.70 & -0.12 & 0.24 & 1.00 & & & \\
\hline$(\mathrm{La} / \mathrm{Sm})_{\mathrm{N}}$ & -0.18 & 0.57 & 0.00 & -0.01 & -0.17 & -0.14 & 0.54 & 0.36 & -0.06 & 0.15 & 0.09 & -0.01 & 0.27 & 0.39 & 0.05 & -0.34 & 0.52 & 0.61 & 0.49 & -0.16 & -0.74 & 0.33 & 0.51 & -0.39 & -0.71 & 0.40 & 1.00 & & \\
\hline$(\mathbf{L a} / \mathbf{Y b})_{\mathrm{N}}$ & 0.02 & 0.86 & -0.24 & 0.34 & -0.02 & -0.25 & 0.74 & 0.66 & 0.38 & 0.32 & 0.42 & 0.03 & 0.64 & 0.75 & 0.03 & -0.10 & 0.68 & 0.88 & 0.52 & 0.25 & -0.65 & 0.69 & 0.74 & -0.21 & -0.48 & 0.72 & 0.85 & 1.00 & \\
\hline$(\mathbf{G d} / \mathbf{Y b})_{\mathrm{N}}$ & 0.20 & 0.94 & -0.40 & 0.45 & 0.26 & -0.37 & 0.86 & 0.84 & 0.53 & 0.45 & 0.46 & 0.27 & 0.79 & 0.86 & 0.24 & 0.21 & 0.58 & 0.93 & 0.47 & 0.37 & -0.39 & 0.84 & 0.78 & -0.27 & -0.20 & 0.87 & 0.70 & 0.95 & 1.00 \\
\hline
\end{tabular}




\section{Genetic model for formation of Mollaahmad Pass bentonite deposits}

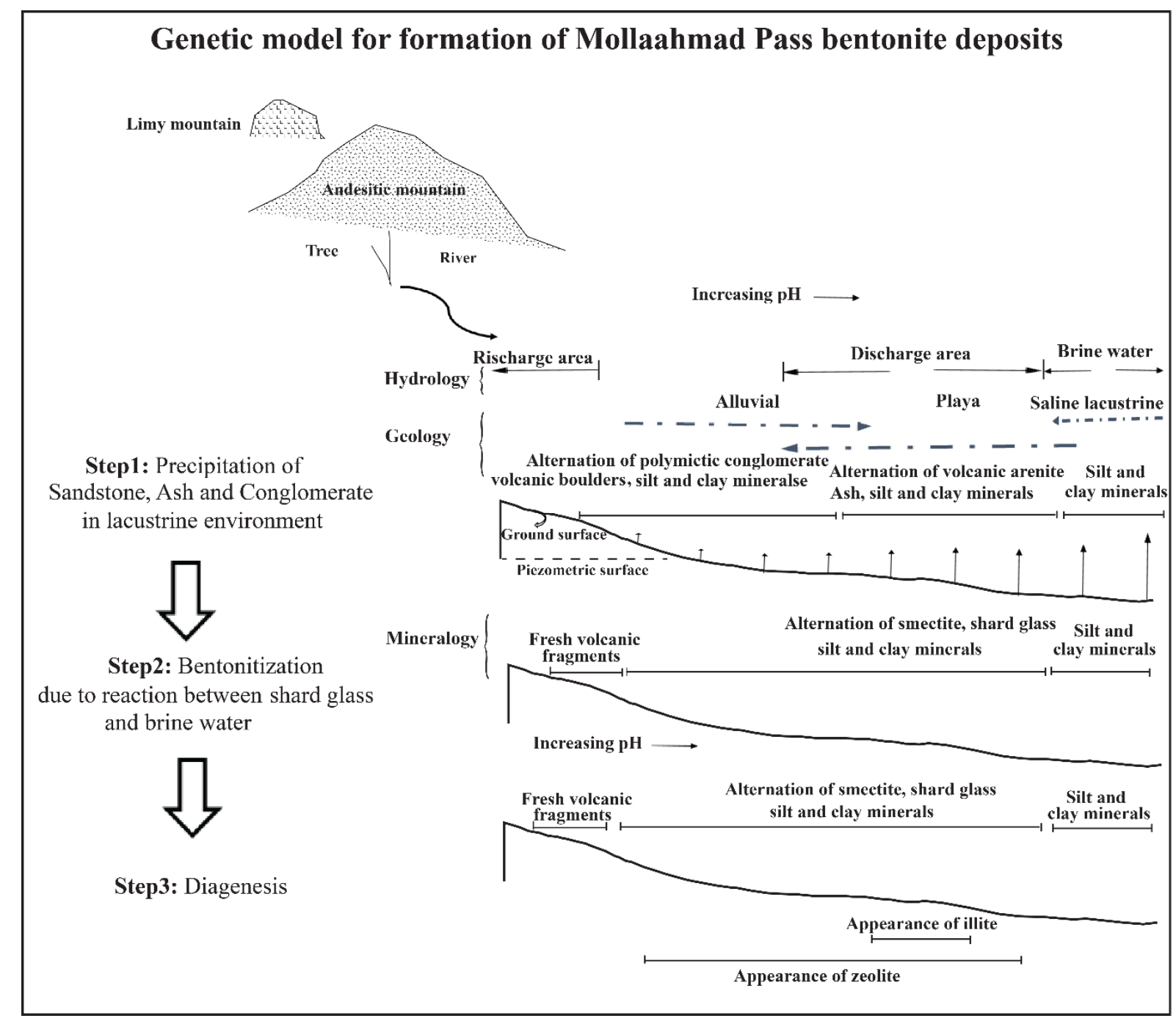

Fig. 26 Schematic model for illustrating genesis of Mollaahmad Pass bentonite deposits in abridged in 3 steps. Step-1: transportation of volcanic boulders, sandstone and conglomerate, tuff with broken wood blocks by river and precipitation near margin of the Oligo-Miocene lacustrine environment. Step-2: Bentonitization: due to chemical reaction between Plagioclase, shard glass and pumice debris with brine water produced enormous deposit of bentonite in Mollahmad area. Step-3: diagenesis process: in this process, with increasing of burial depth, smectite converted to illite and zeolite.

and placement of silt and clay between coarse grain sediments (conglomerate and sandstone), particularly where the surfaces involve more than one transgressive/regressive cycle.

3 Digenesis: with increasing of burial depth, montmorillonite converted to illite and in diagenesis step appears the zeolite group minerals.

In addition, the isotopic studies on $\mathrm{H}$ and $\mathrm{O}$ of smectites in Mehrabad bentonite deposit indicate that meteoric water has strong role in bentonitization process (Mehvari et al., 2009). High percentage of zeolite (clinoptilolite and heulandite) with rang of 8 to $47 \%$, specially associated with Mollaahmad Pass bentonite deposits (Fatahi et al., 2015). The investigation by workers (Fatahi et al., 2015; Calagari et al., 2015; Abedini et al., 2011) indicate that the other studied bentonite deposits in Central Iran zone, such as Tashtab, Sangab, Chahriseh, Neyestanak, and Mehrejan contain zeolite group minerals below $4 \%$. This subject may be related to role of brine water in formation of Mollaahmad Pass bentonite deposits. Initial alteration of the pyroclastics appears to have occurred at or near the pyroclastic/water interface in contact with water ranging in salinity from brackish to marine, as occurred in Wyoming example (Elzea, 1990). This alteration process may have continued for sometimes after other sediments buried the pyroclastic materials (Arslan et al., 2010).

\section{CONCLUSIONS}

The Mollaahmad Pass bentonite deposit about $10 \mathrm{~km}^{2}$ area has extended within conglomerate, sandstone with volcanic fragments and tuff in Oligo- 
Miocene sedimentary basin. Because of presence of non-resistant minerals such as plagioclase, shard glass and pumice debris, interaction occur between them and chemistry and $\mathrm{pH}$ of fluids are responsible for bentonitization. Silicic gel with montmorillonite are released that lead to formation of cristobalite and tridymite.

In Mollaahmad Pass bentonite deposits, the amount of $\mathrm{Na}$ is greater than $\mathrm{Ca}$, so it is called as Wyoming-type bentonites. The geochemical considerations indicate the positive to negative range of $\mathrm{Eu}$ and $\mathrm{Ce}$ anomalies. It mostly is related to change in oxidation-reduction conditions and $\mathrm{pH}$ in environment due to swing of sedimentary basin floor, lake-level fluctuations, mixing of brine water by fresh river water or lacustrine water rotation. The high differentiation between LREE and HREE related to transportation of HREE as carbonates complex by fluids from the system. Distribution pattern of REE in chalcedony filling cavities sample is similar to bentonite and parent rock. This subject attributed to destruction of plagioclase during bentonitization. Eventually, in Mollaahmad Pass bentonite deposits three steps have occurred during its evolution including transportation and precipitation of parent rock in margin of lacustrine environment, bentonitization and diagenesis process.

\section{ACKNOWLEDGMENT}

This work supported financially by research deputy bureau of Universities of Isfahan and Tabriz and Silk Road Explorers Company. The authors would like to express their thanks and appreciations to the authorities of this bureau. Our gratitude is further expressed to editors and reviewers.

\section{REFERENCES}

Abdioglu, E. and Arslan, M.: 2005, Mineralogy, geochemistry and genesis of bentonites of the Ordu area, NE Turkey. Clay Miner., 40, 131-151. DOI: 10.1180/0009855054010161

Abedini, A., Calagari, A.A. and Akbari, M.: 2011, Geochemistry and genesis of Mehrejan bentonite deposit, southeast of Khoor, Isfahan province. Journal of Geopresia, 1, 47-58.

Aja, S.U.: 1998, The sorption of rare earth element, $\mathrm{Nd}$ to kaolinite at $25^{\circ} \mathrm{C}$. Clays Clay Miner., 46, 103-109. DOI: 10.1346/CCMN.1998.0460112

Amini, B. and Amini Chehraq, M.: 2003, Geological map of Kajan, 1/100000 series. Geological survey of Iran, Sheet number 6555 .

Arslan, M., Abdioglu, E. and Kadir, S.: 2010, Mineralogy, geochemistry, and origin of bentonite in upper cretaceous pyroclastic units of the Tirebolu area, Giresun, Northeast Turkey. Clays Clay Miner., 58, No. 1, 120-141. DOI: 10.1346/CCMN.2010.0580112

Bohor, B.F. and Triplehorn, D.M: 1993, Tonsteins: Altered volcanic ash layers in coal-bearing sequence. Geological Society of America, Special papers, 285, 1-44. DOI: 10.1130/SPE285

Brimhall, G.H. and Dietrich, W.E.: 1987, Constitutive mass balance relations between chemical composition, volume, density, porosity, and strain in metasomatic hydrorchemical systems: Results on weathering and pedogenesis. Geochim. Cosmochim. Ac., 51, 567587. DOI: $10.1016 / 0016-7037(87) 90070-6$

Brown, T.H., Berman, R.G. and Perkins, S.: 1988, Geocal II: Ptasystem: Software for the calculation and display of pressure-temperature-activity phase diagrams. British Department of Geological Sciences, Vancouver, British Columbia, manual for computer program. DOI: 10.1016/0098-3004(88)90061-1

Calagari, A.A., Abedini, A. and Fatahi, Sh.: 2015, Mineralogical and geochemical of the Sangab bentonite deposit, Isfahan province, Iran. Neues Jahrbuch für Geologie und Paläontologie, Abhandlugen, 277, 125-139. DOI: $10.1127 /$ njgpa/2015/0504

Cas, R.A.F. and Wright, J.V.: 1988, Volcanic successions, modern and ancient. London: Unwin Hyman. 528. DOI: 10.1007/978-94-009-3167-1

Christidis, G.E.: 1998, Comparative study of the mobility of major and trace elements during alteration of an andesite and a rhyolite to bentonite in the islands of Milos and Kimolos, Aegean, Greece. Clays Clay Miner., 46, 379-399. DOI: $10.1346 / C C M N .1998 .0460403$

Christidis, G.: 2001, Formation and growth of smectites in bentonites: A case study from Kimolos Island, Aegean", Greece. Clays Clay Miner., 49(3), 204-215. DOI: 10.1346/CCMN.2001.0490303

Christidis, G.E.: 2008, Validity of the structural formula method for layer charge determination of smectite: A re-evaluation of published data. Appl. Clay Sci., 42, 1-7. DOI: 10.1016/j.clay.2008.02.002

Christidis, G.E. and Dunham, A.C.: 1996, Compositional variation in smectites part II. Alteration of acidic precursors: a case study from Milos Island, Greece. Clay Miner., 32, 253-270.

DOI: 10.1180/claymin.1997.032.2.07

Christidis, G.E. and Huff, W.D.: 2009, Geologic aspects and genesis of bentonites. Elements, 5, 93-98. DOI: $10.2113 /$ gselements.5.2.93

Christidis, G.E., Scott, P.W. and Marcopoulas, T.: 1995, Origin of the bentonite deposits of Eastern Milos and Kimalos, Greece: Geology, geological, mineralogical and geochemical evidence. Clays Clay Miner., 43, 6377. DOI: 10.1346/CCMN.1995.0430108

Coombs, D.S., Ellis, A.J., Fyfe, W.S. and Taylor, A.M.: 1959, The zeolite facies, with comments on the interpretation of hydrothermal syntheses. Geochim. Cosmochim. Ac., 17, 53-107. DOI: 10.1016/0016-7037(59)90079-1

Costa, M.L. and Araujo, E.S.: 1996, Application of multielement geochemistry in Au-phosphate-bearing lateritic crusts for identification of their parent rocks. J. Geochem. Explor., 57, 257-272.

DOI: 10.1016/S0375-6742(96)00041-6

Cox, K.G., Bell, J.D. and Pankhurst, R.J.: 1979, The interpretation of igneous rocks. George Allen and Unwin, London, $450 \mathrm{pp}$. DOI: $10.1007 / 978-94-017-3373-1$

Elzea, J.M.: 1990, Geology, geochemistry, selected physical properties and genesis of the Cretaceous Clay Spur bentonite in Wyoming and Montona, USA. PhD thesis, Indiana University, USA. 201 pp. 
Elzea, J.M. and Murray, H.H.: 1990, Variation in the mineralogical, chemical and physical properties of the Cretaceous Clay Spur bentonite in Wyoming and Montana (U.S.A.). Appl. Clay Sci., 5, 229-248.

DOI: 10.1016/0169-1317(90)90012-E

Fatahi, Sh., Calagari, A.A., Abedini, A. and Bagheri, H.: 2015, The mineralogical, geochemical, and genetic features of Naein-Khoor bentonite horizon in the Central Iran zone. Ph.D. Dissertation, Tabriz University, 239 pp.

Fisher, R.V. and Schmincke, H.U.: 1984, Pyroclastic Rocks. Springer-Verlag, Berlin, $472 \mathrm{pp}$. DOI: 10.1007/978-3-642-74864-6

Folk, R.L.: 1974, Petrography of sedimentary Rocks. Hemphill publishing Co. Texas, 182 pp.

Fung, P.C. and Shaw, D.M.: 1978, Na, Rb and Tl distributions between phlogopite and sanidine by direct synthesis in common vapour phase. Geochim. Cosmochim. Ac., 56, 899-909. DOI: $10.1016 / 0016-7037(78) 90088-1$

Garrels, R.M.: 1984, Montmorillonite-illite stability diagrams. Clays Clay Miner., 32, 161-96. DOI: 10.1346/CCMN.1984.0320301

Ge, X., Mou, C., Wang, C., Men, X., Chen, C. and Hou, Q.: 2019, Mineralogical and geochemical characteristics of K-bentonites from the Late Ordovician to the Early Silurian in South China and their geological significance. Geol. J., 54, 1, 514-528.

DOI: $10.1002 / \mathrm{gj} .3201$

Goldstein, S.J. and Jacobsen, S.B.: 1988, Rare earth element in river waters. Earth Planet. Sci. Lett., 89, 35-47.

DOI: $10.1016 / 0012-821 X(88) 90031-3$

Gotze, J., Nasdala, L., Kleeberg, R. and Wenzel, M.: 1998, Occurrence and distribution of "Moganite" in agate/chalcedony: A combine micro- Roman, Rietveld, and cathodoluminescence study. Contrib. Mineral. Petr., 133, 96-105.

DOI: $10.1007 / \mathrm{s} 004100050440$

Grim, R.E. and Kulbicki, G.:1961, Montmorillonite: High temperature reactions and classification. Am. Mineral., 46, 1329-1369.

Guven, N.: 1988, Smectites in: Bailey, S.W. (Ed.), Hydrous Phyllosilicates: Reviews in mineralogy. Mineralogical Society of America, Rev. Mineral., 19, 497-559.

Hay, R.L.:1977, Geology of zeolites in sedimentary rocks in: Mineralogy and Geology of Natural Zeolites (F.A. Mumpton, editor). Mineralogical Society of America, Washington, D.C., Rev. Mineral., 4 53-64.

Hay, R.L. and Guldman, S.G.: 1987, Diagenetic alteration of silicic ash in Searles Lake, California. Clays Clay Miner., 35, 449-457. DOI: 10.1346/CCMN.1987.0350605

Hong, H., Zhao, L., Fang, Q., Algeo, T.J., Wang, C., Yu, J. and Ji, K.: 2019, Volcanic sources and diagenetic alteration of Permian-Triassic boundary K-bentonites in Guizhou Province, South China. Palaeogeogr. Palaeoclimatol. Palaeoecol., 519, 141-153.

DOI: $10.1016 /$ j.palaeo.2018.01.019
Iijima, A.: 1980, Geology of natural zeolites and zeolitic rocks. Proc. 5th Int. Conf. on zeolites, 103-118. DOI: $10.1351 /$ pac 198052092115

Inoue, A.:1995, Formation of clay minerals in hydrothermal environments. Origin and mineralogy of clays, 268 329. DOI: 10.1007/978-3-662-12648-6_7

Inoue, A., Utada, M. and Wakita, K: 1992, Smectite- toillite conversation in natural hydrothermal systems. App Clay Sci, 7, 131-145. DOI: 10.1016/0169-1317(92)90035-L

Irvine, T.N. and Baragar, W.R.A.: 1971, A guide to the chemical classification of the common volcanic rocks. J. Earth Sci., 8, 523-548. DOI: $10.1139 /$ cjes-2018-0056

Jiang, N., Sun, S.H., Chu, X., Mizuta, T. and Ishiyama, D.: 2003, Mobilization and enrichment of high-field strength elements during late- and post-magmatic processes in the Shuiquangou syenitic complex, Northern China. Chem. Geol., 200, 117-128. DOI: 10.1016/S0009-2541(03)00162-1

Kadir, S., Kulah, T., Erkoyun, H., Christidis, G. and Arslanyan, F.: 2019, Geology, mineralogy, geochemistry, and genesis of bentonite deposits in Miocene Volcano-Sedimentary units of the Balikesir region, Western Anatolia, Turkey. Clays Clay Miner. DOI: $10.1007 / \mathrm{s} 42860-019-00029-\mathrm{w}$

Kadir, S., Kulah, N., Onalgil, N, Erkoyun, H. and Elliott, W.C.: 2017, Mineralogy, geochemistry and genesis of bentonites in Miocene Volcanic-Sedimentary units of the Ankara-Cankiri basin, central Anatolia, Turkey. Clays Clay Miner., 65, No. 2, 64-91 DOI: 10.1346/CCMN.2017.064051

Karakaya, C.K., Karakaya, N. and Bakır, S.: 2011a, Some properties and potential applications of the $\mathrm{Na}-$ and Ca-bentonites of ordu (N.E. Turkey). Appl. Clay Sci., 54, 159-165. DOI: 10.1016/j.clay.2011.08.003

Karakaya, M.C., Karakaya, N. and Kupeli, S.: 2011b, Mineralogical and geochemical properties of the $\mathrm{Na}$ and Ca-Bentonites of Ordu (NE Turkey). Clays Clay Miner., 59, No. 1, 75-94. DOI: 10.1346/CCMN.2011.0590109

Knetchel, M.M. and Patterson, S.H.: 1962, Bentonite deposits of the northern Black Hills district, Wyoming, Montana, and South Dakota. Bull. US Geol. Surv., 1082. DOI: $10.3133 / \mathrm{b} 1082 \mathrm{M}$

Köster, M.H., Williams, L.B., Kudejova, P. and Gilg, H.A.: 2019, The boron isotope geochemistry of smectites from sodium, magnesium and calcium bentonite deposits. Chem. Geol., 510, 166-187. DOI: $10.1016 /$ j.chemgeo.2018.12.035

Kretz, R.: 1983. Symbols for rock-forming minerals. Am. Mineral., 68, 277-279.

Laufer, F., Yariv, S. and Steinberg, M.: 1984, The adsorption of quadrivalent cerium by kaolinite. Clay minerals, 19 , 137-149. DOI: 10.1180/claymin.1984.019.2.02

Laviano, R. and Mongelli, G.: 1996, Geochemistry and mineralogy as indicators of parental affinity for Cenozoic bentonites: A case study from S. Croce Di Magliano (southern Appennines, Italy). Clay Miner., 31, 391-401.

Lopez, J.M.G., Bauluz, B., Nieto, C.F. and Oliete, A.Y.: 2005, Factors controlling the trace elements distribution in fine grained rocks: The Albian Kaolinite rich deposits of the Oliete Basin (NE Spain). Chem. Geol., 214, 1-19.

DOI: 10.1016/j.chemgeo.2004.08.024 
Manning, D.A.C.: 1995, Introduction to industrial minerals. Chapman and Hall, London, 279pp.

Mariner, R.H. and Surdam, R.C.: 1970, Alkalinity and formation of zeolites in saline, alkaline lakes. Science, 170, 977-980. DOI: 10.1126/science.170.3961.977

Mason, B.H. and Moore, C.B.:1982, Principles of geochemistry. New York, John Wiley and Sons, $241 \mathrm{pp}$.

Mehvari, R., Noghreheeian, M. and Kouhsari, A.H.: 2009, The petrology and mineralogy study of Mollaahmad pass hydrothermal alteration (Bentonitization and Silisification) (east of Esfahan). Master Thesis, Isfahan University, $160 \mathrm{pp}$.

Modabberi, S., Namayandeh, A., Setti, M. and LópezGalindo, A.: 2019, Genesis of the Eastern Iranian bentonite deposits. Appl. Clay Sci., 168, 56-67. DOI: $10.1016 /$ j.clay.2018.10.011

Muchangos, A.C.: 2006, The mobility of rare earth and other elements in process of alteration of rhyolitic rocks to bentonite (Lebombo Volcanic Mountainous Chain, Mozambigue), J. Geochem. Explor., 88, 300-303. DOI: 10.1016/j.gexplo.2005.08.061

Munch, P., Duplay, J. and Cocheme, J.J.: 1 996, Alteration of silicic vitric tuffs interbedded in volcanoclastic deposits of the Southern Basin and Range Province, Mexico: Evidences for hydrothermal reaction. Clays Clay Miner., 44, 49-67. DOI: $10.1346 / C C M N .1996 .0440105$

Nabavi, M.H. :1976, Introduction of geology of Iran. Geological survey of Iran, 105.

Ozdamar, S., Ece, O.I., Uz, B., Boylu, F.B., Ercan, H.U. and Yanik, G.: 2014, Element mobility during the formation of the Uzunisa-Ordu bentonite, NE Turkey, and potential applications. Clay Miner., 49, 609-633. DOI: 10.1180/claymin.2014.049.5.01

Pandarinath, K., Dulski, P., Torres-Alvarado, I. S. and Verma, S.P.: 2008, Element mobility during the hydrothermal alteration of rhyolitic rocks of the los Azufres geothermal field Mexico. Geothermics, 37, 53-72. DOI: 10.1016/j.geothermics.2007.10.002

Parker, S.P.: 1988, Encyclopaedia of the geological sciences, 2nd ed. New York, McGraw-Hill, 32-33, 69-72, 400-401.

Plank, T. and Langmuir, C.H.: 1988, The chemical composition of subducting sediment and its consequences for the crust and mantle. Chem. Geol., $145,325-394$.

DOI: 10.1016/S0009-2541(97)00150-2

Pointon, M.A., Chew, D.M., Delcambre, B., and Sevastopulo, G.D.: 2018, Geochemistry and origin of Carboniferous (Mississippian; Viséan) bentonites in the Namur-Dinant Basin, Belgium: evidence for a Variscan Volcanic source. Geol. Belg., 21, 1. DOI: $10.20341 / \mathrm{gb} .2017 .011$

Rollinson, H.: 1993, Using geochemical data: Evaluation, Presentation, Interpretation, 352. DOI: $10.4324 / 9781315845548$

Savage, D., Walker, C., Arthur, R., Rochelle, C.H., Oda, C.H. and Takase, H.: 2007, Alteration of bentonite by hyperalkaline fluids: A review of the role of secondary minerals. Phys. Chem. Earth, 32, 287-297.

DOI: $10.1016 /$ j.pce.2005.08.048
Scott, J.J., Buatois, L.A. and Mangano, M.G.: 2012, Lacustrine environments. Developments in Sedimentology, 64, 379-417.

DOI: 10.1016/B978-0-444-53813-0.00013-7

Senkayi, A.L., Dixon, J.B., Hossner, L.R., Abder-Ruhman, M. and Fanning, D.S.: 1984, Mineralogy and genetic relationships of tonstein, bentonite and lignitic strata in the Eocene Yegna Formation of East-Central Texas. Clays Clay Miner., 32, 259-271.

DOI: $10.1346 / C C M N .1984 .0320403$

Sheppard, R.A. and Gude, A.J.: 1973, Zeolites and associated authigenic silicate minerals in tuffaceous rocks of the Big Sandy Formation, Mohave County, Arizona. U.S. Geological Survey Professional Paper, $830,836$.

Shiraki R. and Iijama, T.: 1990, Na- K ion exchange reaction between rhyolitic glass and $(\mathrm{Na}, \mathrm{K}) \mathrm{Cl}$ aqueous solution under hydrothermal conditions. Geochim. Cosmochim. Ac. 54, 2923-2931. DOI: 10.1016/0016-7037(90)90110-7

Taylor, S.R.: 1964, Abundance of chemical elements in the continental crust: a new table. Geochim. Cosmochim. Ac., 28, 1273-1285. DOI: $10.1016 / 0016-7037(64) 90129-2$

Taylor, S.R. and McLennan, S.M.: 1985, The Continental Crust: Its Composition and Evolution. Blackwell, Oxford 312. DOI: $10.1002 / \mathrm{gj} .3350210116$

Velde, B.: 1992, Introduction to clay minerals, Chapman and Hall, 198.

Vogt, K. and Kostner, H.M.: 1978, Zur Mineralogie, Kristallchemie und Geochemie einiger Montmorillonite aus Bentoniten, Clay Miner., 13, 2543. DOI: 10.1180 /claymin. 1978.013.1.03

Weaver, C.E. and Pollard, L.D.: 1973, The Chemistry of Clay Minerals. Elsevier, Amsterdam, 213.

White, A.F. and Claasen, H.C.: 1980, Kinetic model for short- term dissolution of a rhyolitic glass. Chem. Geol., 28, 91-109. DOI: 10.1016/0009-2541(80)90038-8

Whitney, D.L. and Evans, B.W.: 2010, Abbreviations for names of rock-forming minerals. Am. Mineral., 95,185-187. DOI: 10.2138/am.2010.3371

Winchester, J.A. and Floyd, P.A.:1977, Geochemical discrimination of different magma series and their differentiation products using immobile elements. Chem. Geol., 20, 325-343. DOI: $10.1016 / 0009-2541(77) 90057-2$

Zeilinski, R.A.:1982, The mobility of uranium and other elements during alteration of rhyolite ash to montmorillonite: a case study in the Troublesome formation, Colorado, U.S.A. Chem. Geol., 35, 185204. DOI: $10.1016 / 0009-2541(82) 90001-8$ 